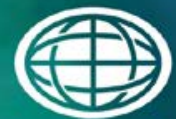

Savannah River

National Laboratory

OPERATED BY SAVANNAH RIVER NUCLEAR SOLUTIONS

\title{
Radionuclide Inventory and Distribution: Fourmile Branch, Pen Branch, and Steel Creek IOUs
}

Robert A. Hiergesell

Mark A. Phifer

April 2014

SRNL-STI-2013-00592, Revision 0 
SRNL-STI-2013-00592

Revision 0

\section{DISCLAIMER}

This work was prepared under an agreement with and funded by the U.S. Government. Neither the U.S. Government or its employees, nor any of its contractors, subcontractors or their employees, makes any express or implied:

1. warranty or assumes any legal liability for the accuracy, completeness, or for the use or results of such use of any information, product, or process disclosed; or

2. representation that such use or results of such use would not infringe privately owned rights; or

3. endorsement or recommendation of any specifically identified commercial product, process, or service

Any views and opinions of authors expressed in this work do not necessarily state or reflect those of the United States Government, or its contractors, or subcontractors.

Printed in the United States of America

Prepared for

U.S. Department of Energy 
Keywords: : Inventory, $F M B, P B, S C$ IOU

Retention: Permanent

\section{Radionuclide Inventory and Distribution: Fourmile Branch, Pen Branch, and Steel Creek IOUs}

Robert A. Hiergesell

Mark A. Phifer

April 2014

Prepared for the U.S. Department of Energy under 


\section{REVIEWS AND APPROVALS}

AUTHORS:

Robert A. Hiergesell, Radiological Performance Assessment, SRNL

Date

Mark A. Phifer, Radiological Performance Assessment, SRNL

Date

TECHNICAL REVIEW: (Reviewed per E7 2.60)

Kenneth L. Dixon, Environmental Restoration Technologies, SRNL

Date

APPROVAL:

David A. Crowley, Manager

Date

Radiological Performance Assessment, SRNL

Robert S. Aylward, Manager

Date

Environmental Restoration Technologies, SRNL

Catherine M. Lewis, Manager

Date

SGW-Remediation Support, EC\&ACP 
SRNL-STI-2013-00592

Revision 0

\section{EXECUTIVE SUMMARY}

As a condition to the Department of Energy (DOE) Low Level Waste Disposal Federal Facility Review Group (LFRG) review team approving the Savannah River Site (SRS) Composite Analysis (CA), SRS agreed to follow up on a secondary issue, which consisted of the consolidation of several observations that the team concluded, when evaluated collectively, could potentially impact the integration of the CA results. This report addresses secondary issue observations 4 and 21, which identify the need to improve the CA sensitivity and uncertainty analysis specifically by improving the CA inventory and the estimate of its uncertainty. The purpose of the work described herein was to be responsive to these secondary issue observations by re-examining the radionuclide inventories of the Integrator Operable Units (IOUs), as documented in ERD 2001 and Hiergesell, et. al. 2008. The LFRG concern has been partially addressed already for the Lower Three Runs (LTR) IOU (Hiergesell and Phifer, 2012). The work described in this investigation is a continuation of the effort to address the LFRG concerns by reexamining the radionuclide inventories associated with Fourmile Branch (FMB) IOU, Pen Branch (PB) IOU and Steel Creek (SC) IOU.

The overall approach to computing radionuclide inventories for each of the IOUs involved the following components:

- Defining contaminated reaches of sediments along the IOU waterways

- Identifying separate segments within each IOU waterway to evaluate individually

- Computing the volume and mass of contaminated soil associated with each segment, or "compartment"

- $\quad$ Obtaining the available and appropriate Sediment and Sediment/Soil analytical results associated with each IOU

- $\quad$ Standardizing all radionuclide activity by decay-correcting all sample analytical results from sample date to the current point in time,

- $\quad$ Computing representative concentrations for all radionuclides associated with each compartment in each of the IOUs

- $\quad$ Computing the radionuclide inventory of each DOE-added radionuclide for the compartments of each IOU by applying the representative, central value concentration to the mass of contaminated soil

- $\quad$ Totaling the inventory for all compartments associated with each of the IOUs

Using this approach the 2013 radionuclide inventories for each sub-compartment associated with each of the three IOUs were computed, by radionuclide. The inventories from all IOU compartments were then rolled-up into a total inventory for each IOU. To put the computed estimate of radionuclide activities within FMB, PB, and SC IOUs into context, attention was drawn to Cs-137, which was the radionuclide with the largest contributor to the calculated dose to a member of the public at the perimeter of SRS within the 2010 SRS CA (SRNL 2010). The total Cs-137 activity in each of the IOUs was calculated to be 9.13, 1.5, and 17.4 Ci for FMB, PB, and SC IOUs, respectively.

Another objective of this investigation was to address the degree of uncertainty associated with the estimated residual radionuclide activity that is calculated for the FMB, PB, and SC IOUs. Two primary contributing factors to overall uncertainty of inventory estimates were identified and evaluated. The first related to the computation of the mass of contaminated material in a particular IOU compartment and the second to the uncertainty associated with analytical counting 
errors. The error ranges for the mass of contaminated material in each IOU compartment were all calculated to be approximately $+/-9.6 \%$, or a nominal $+/-10 \%$. This nominal value was added to the uncertainty associated with the analytical counting errors that were associated with each radionuclide, individually. This total uncertainty was then used to calculate a maximum and minimum estimated radionuclide inventories for each IOU. 


\section{TABLE OF CONTENTS}

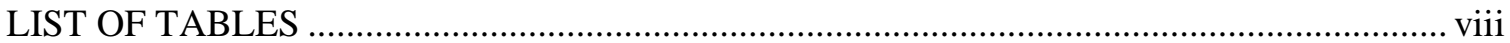

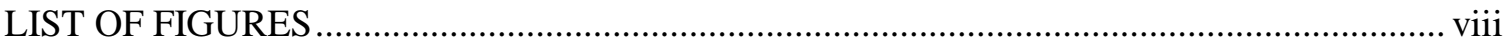

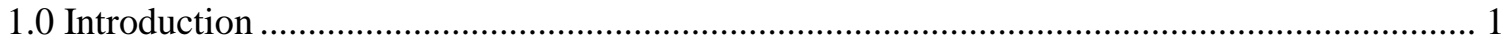

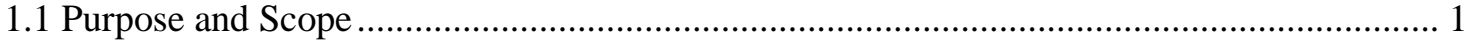

1.2 Description of Fourmile Branch, Pen Branch, and Steel Creek Integrator Operable Units... 2

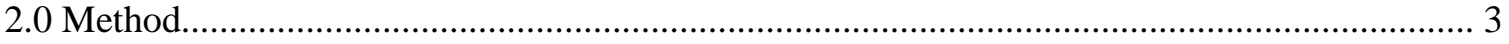

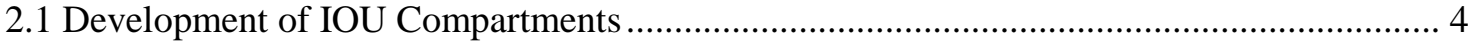

2.1.1 Fourmile Branch Watershed........................................................................................... 4

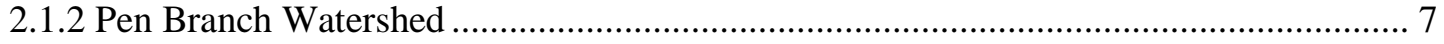

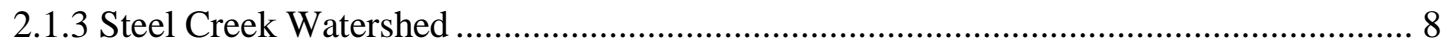

2.2 Sediment and Soil/Sediment Data Processing .................................................................... 9

2.3 Estimating the Mass of Contaminated Sediment and Sed/Soil........................................... 12

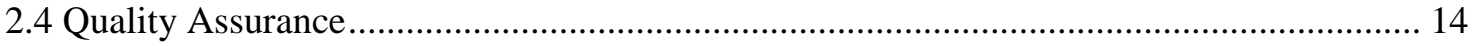

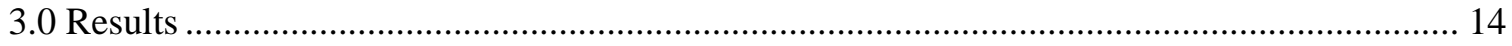

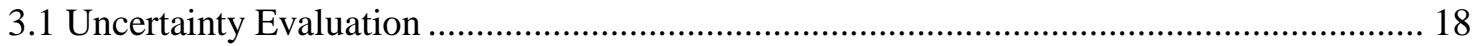

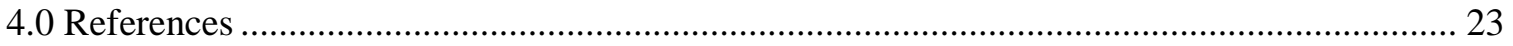

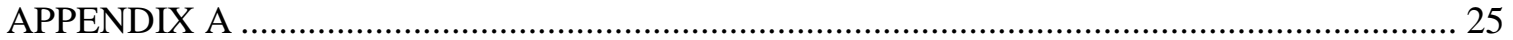

Sediment and Soil/Sediment Analytical Data for each FMB, PB, and SC IOU Sub-Compartments 25

APPENDIX B

Error! Bookmark not defined.

FMB, PB, and SC IOUs Sub-Compartment Dimensions and Computation of Contaminated Soil Volume and Mass Error! Bookmark not defined.

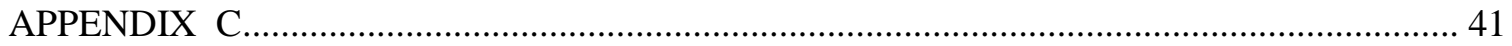

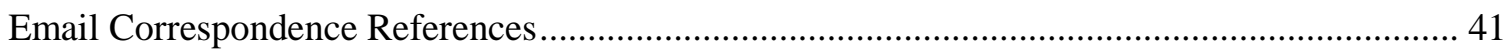




\section{LIST OF TABLES}

Table 3-1 Summary of Radionuclide Inventories for FMB IOU Compartments...................... 14

Table 3-2 Summary of Radionuclide Inventories for the Pen Branch IOU ............................ 15

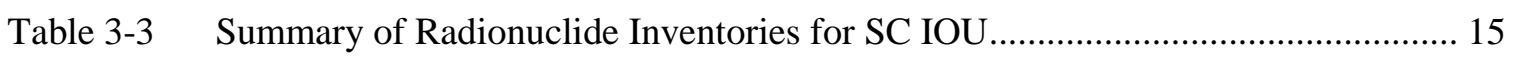

Table 3-4 Radionuclide Total Inventory Roll-up for FMB IOU, PB IOU and SC IOU .......... 16

Table 3-5 Previously Reported Cs-137 Inventories for FMB, PB, and SC IOUs .................... 16

Table 3-6. Estimated Aggregate Analytical Uncertainty by Radionuclide .............................. 20

Table 3-7. Total Uncertainty Associated with Radionuclide Inventory Estimates.................... 21

Table 3-8 Upper and Lower Bounding Radionuclide Inventory Estimates ............................. 22

Table A-0-1 FMB Compartments - Samples, Mean Concentrations and Inventories ............... 26

Table A-0-2 PB Compartments - Samples, Mean Concentrations and Inventories ................. 30

Table A-0-3 SC Compartments - Samples, Mean Concentrations and Inventories................. 32

Table B-0-1. FMB Compartments - Volume and Mass of Contaminated Media...................... 36

Table B-0-2. PB Compartments - Volume and Mass of Contaminated Media ......................... 38

Table B-0-3. SC Compartments - Volume and Mass of Contaminated Media ......................... 39

\section{LIST OF FIGURES}

Figure 1-1. Location of FMB, PB, and SC Watersheds ...................................................... 3

Figure 2-1 Delineation of Fourmile Branch Compartments..................................................... 5

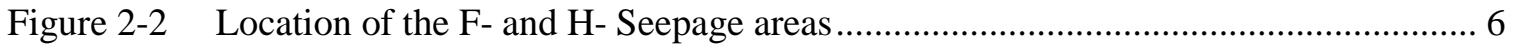

Figure 2-3 Location of F-Area and H-Tank Farm tributaries to FMB ..................................... 6

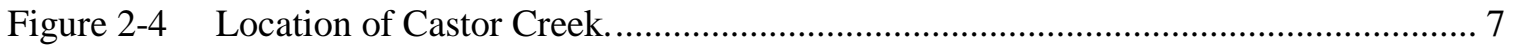

Figure 2-5 Delineation of Pen Branch Compartments .......................................................... 7

Figure 2-6 Delineation of Steel Creek Compartments ........................................................ 9 


\section{LIST OF ACRONYMS}

$\begin{array}{ll}\text { ArcMap } & \text { Geographic Information System Program } \\ \text { CA } & \text { Composite Analysis } \\ \text { CSM } & \text { Conceptual Site Model } \\ \text { DOE } & \text { Department of Energy } \\ \text { ERD } & \text { Environmental Restoration Department } \\ \text { EC\&ACP } & \text { Environmental Compliance \& Area Completions Project } \\ \text { FMB } & \text { Fourmile Branch } \\ \text { GIS } & \text { Geographic Information System } \\ \text { GSA } & \text { General Separations Area } \\ \text { IOU } & \text { Integrator Operable Unit } \\ \text { LIDAR } & \text { Light Detection and Ranging } \\ \text { LFRG } & \text { Low Level Waste Disposal Facility Federal Review Group } \\ \text { LTR } & \text { Lower Three Runs } \\ \text { MDL } & \text { Method Detection Limit } \\ \text { NPDES } & \text { National Pollutant Discharge Elimination System } \\ \text { PB } & \text { Pen Branch } \\ \text { POA } & \text { Point of Assessment } \\ \text { SC } & \text { Steel Creek } \\ \text { SGIS\&ES } & \text { Site GIS and Environmental Systems } \\ \text { SR } & \text { Savannah River } \\ \text { SRNL } & \text { Savannah River National Laboratory } \\ \text { SRNS } & \text { Savannah River Nuclear Solutions } \\ \text { SRS } & \text { Savannah River Site } \\ \text { WSRC } & \text { Westinghouse or Washington Savannah River Company } \\ & \end{array}$


SRNL-STI-2013-00592

Revision 0

This Page Intentionally Left Blank 
SRNL-STI-2013-00592

Revision 0

\subsection{Introduction}

In 2010 the Savannah River National Laboratory (SRNL) completed a Composite Analysis (CA) of the U.S. Department of Energy's (DOE's) Savannah River Site (SRS). That investigation evaluated the dose impact of the anticipated SRS End State residual sources of radionuclides to offsite members of the public. The CA evaluated doses to members of the public at the locations where SRS site streams discharge into the Savannah River (SR). The models developed to perform this computation indicated that the dose constraint (30 mrem/yr) associated with the CA would not be approached at any of the points of assessment (POAs), located at the mouths of SRS streams where they discharge into the SR. The streams and floodplains of Fourmile Branch (FMB), Pen Branch (PB) and Steel Creek (SC) form three of the six SRS Integrator Operable Units (IOUs) corresponding to each of the major onsite watersheds and the portion of the SRS adjacent to the SR. IOU's are defined as surface water bodies and associated wetlands, including the stream sediment (submerged below water), floodplain sediment/soil, and related biota. IOUs are evaluated to determine if past releases of contamination from SRS pose unacceptable risks to the environment, SRS workers, or off-site members of the public. The primary focus of this evaluation of radionuclide releases associated with IOUs is on those residual radionuclides adsorbed to the shallow pond and streambed sediments and the soils that lie within the associated floodplains.

\subsection{Purpose and Scope}

DOE provided conditional approval of the SRS CA (SRNL 2010) on July 16, 2010 (Marcinowski 2010). Approval was provided with the condition that the secondary issue identified by the Low Level Waste Disposal Facility Federal Review Group (LFRG) review team (Carilli and Golian 2010) be resolved. The secondary issue identified by the LFRG review team consisted of the consolidation of eighteen observations that the team concluded, when evaluated collectively, could potentially impact the integration of the CA results. Nine of these secondary issue observations, which involved missing information, were resolved by additions to the CA prior to its approval. Specific future work items were added to the CA maintenance plan to provide a path forward for the resolution of the other nine secondary issue observations. This included secondary issue observations 4 and 21, which identify the need to improve the CA sensitivity and uncertainty analysis specifically by improving the CA inventory and the estimate of its uncertainty. Hence, the purpose of the work described herein, was to be responsive to these secondary issue observations by re-examining the radionuclide inventories of the IOUs, as documented in previous investigations (ERD 2001 and Hiergesell et. al, 2008). The LFRG concern has been partially addressed for the Lower Three Runs (LTR) IOU (Hiergesell and Phifer, 2012) by the completion of the evaluation for LTR. The work described in this investigation is a continuation of the effort to address the LFRG concerns by re-examining the radionuclide inventories associated with FMB, PB, and SC IOUs. Eventually, the residual radionuclide inventories of the remaining SRS IOUs will be re-evaluated to fully address the concern.

The scope of this effort included the evaluation of sampling and analysis data that existed at the time of the previous inventory estimate, as well as the additional streambed and floodplain sampling and analysis data acquired afterwards as part of the ongoing SRS IOU program, and specifically for the FMB, PB, and SC IOUs. While Cs-137 is the most significant and abundant radionuclide associated with the FMB, $\mathrm{PB}$, and SC IOUs, it is not the only radionuclide present; hence the scope includes evaluating all radionuclides having a SRS operational source and for 
which data are available, and includes an evaluation of inventory uncertainty for use in sensitivity and uncertainty analyses. The scope also involved evaluation of the radionuclide inventory associated with the sediments of L-Lake, which is an impoundment constructed on SC and is part of SC IOU.

\subsection{Description of Fourmile Branch, Pen Branch, and Steel Creek Integrator Operable Units}

FMB, PB, and SC IOUs are located adjacent to one another in the south-central portion of SRS. The watershed boundary associated with each IOU is shown by the areas outlined in red in Figure 1-1. Each watershed contains facilities and outfalls, as well as waste units in various stages of the remediation process that may represent a potential impact to the associated IOU depending on groundwater and surface water flow paths.

FMB originates near the center of SRS and follows a southwesterly direction for approximately $24 \mathrm{~km}(15 \mathrm{mi})$. The watershed drains about $57 \mathrm{~km}^{2}\left(22 \mathrm{mi}^{2}\right)$ and includes the footprint of all or parts of several SRS facility areas: all of C-Area (C Reactor), the majority of N-Area (Central Shops), and the portion of F-, H-, and E-Areas (General Separations Area) located within those watershed boundaries. At its headwaters, FMB is a small backwater stream un-impacted by historical SRS operations. FMB has historically and currently receives effluents from F-, H-, and C-Areas, as well as contaminated groundwater discharges that have migrated from SRS facilities and waste units into the stream and its tributaries (WSRC 2008). The FMB IOU is defined as FMB and its tributaries (including surface water and groundwater seeps), sediment (below water surface), sediment/soil (floodplain soil), and related biota in these streams and their associated floodplains. This area represents integration of potential contaminant exposure pathways to onsite human and ecological receptors from potential SRS contaminant sources. FMB discharges into the SR swamp prior to discharging into the SR, which is the exposure point for offsite members of the public.

PB originates near the center of SRS and follows a southwesterly direction for approximately 18 $\mathrm{km}(11 \mathrm{mi})$. The watershed drains about $56 \mathrm{~km}^{2}\left(21 \mathrm{mi}^{2}\right)$ and includes the entirety of K-Area (KReactor) and a portion of N-Area. The PB IOU is defined as PB and its tributaries, including surface water, sediment, sediment/soil, and related biota within these streams and the associated floodplains (WSRC 2001). PB enters into the SR swamp prior to discharging into the SR at the mouth of SC and the SR.

SC is located in the southeast portion of SRS, between PB and LTR, and flows southwesterly for approximately $17.5 \mathrm{~km}(10.6 \mathrm{mi})$ before entering the SR via the SR swamp and discharging into the SR. The watershed drains about $91 \mathrm{~km}^{2}\left(35 \mathrm{mi}^{2}\right)$ and includes L-Lake, a cooling water reservoir that is approximately $6.5 \mathrm{~km}(4 \mathrm{mi})$ long and relatively narrow, encompassing an area of

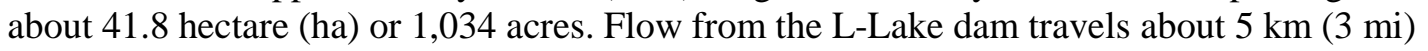
before entering the SR swamp and then another $3 \mathrm{~km}(1.8 \mathrm{mi})$ before entering the SR. Meyers Branch is the main tributary of SC and flows approximately $10 \mathrm{~km}(6.2 \mathrm{mi})$ before entering SC below L-Lake. Meyers Branch is a small stream that has remained relatively undisturbed by SRS operations. 


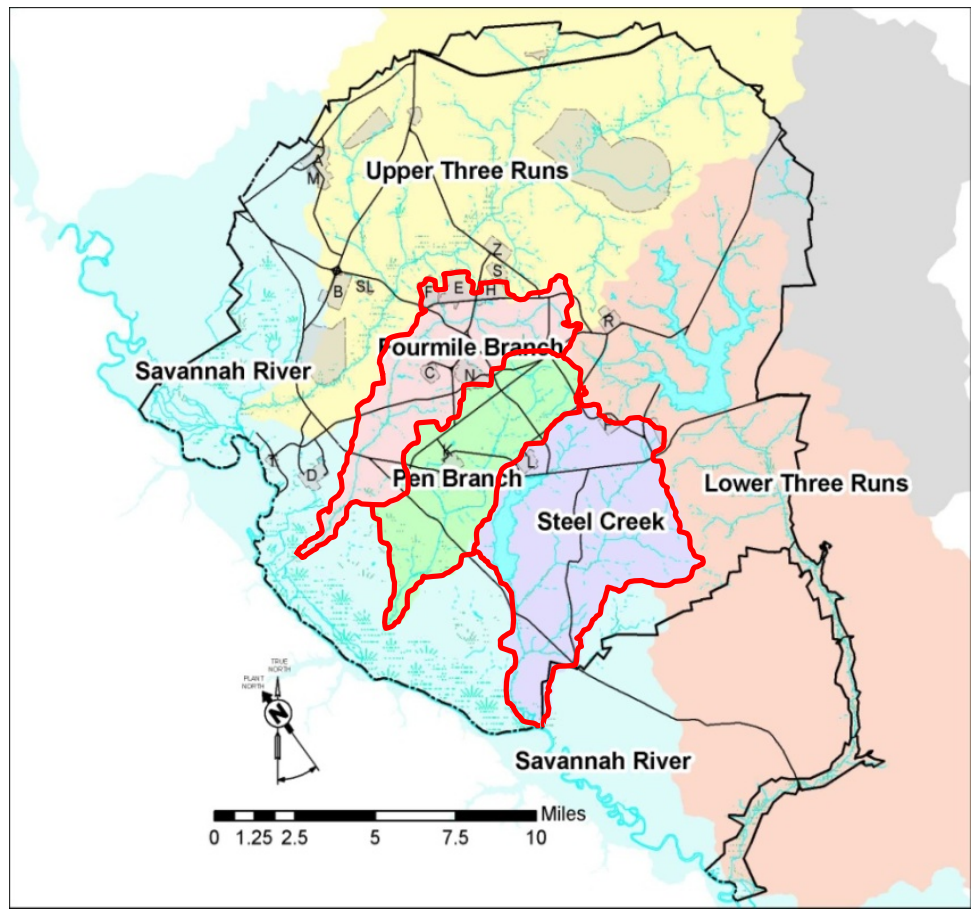

Figure 1-1. Location of FMB, PB, and SC Watersheds

\subsection{Method}

The overall approach to computing radionuclide inventories for each of the IOUs involved the following components:

- $\quad$ Defining contaminated reaches of sediments along the IOU waterways

- $\quad$ Identifying separate segments within each IOU waterway to evaluate individually

- $\quad$ Computing the volume and mass of contaminated soil associated with each segment, or "compartment"

- $\quad$ Obtaining the available and appropriate Sediment and Sed/Soil analytical results associated with each IOU

- Standardizing all radionuclide activity by decay-correcting all sample analytical results from sample date to the current point in time

- $\quad$ Computing representative concentrations for DOE-added radionuclides associated with each compartment in each of the IOUs

- $\quad$ Computing the radionuclide inventory of each radionuclide for the compartments of each IOU by applying the representative concentration to the mass of contaminated soil

- $\quad$ Totaling the inventory for all compartments associated with each of the IOUs

The first step in the investigation was to obtain all of the available sample data for the FMB, PB, and SC IOUs. As part of their IOU program, Environmental Compliance and Area Completion Project (EC\&ACP) has a database that includes Sediment and Sed/Soil Samples that have been collected in support of the IOU program or for other SRS operational or research investigations. 
The data base is maintained by Site GIS and Environmental Systems (SGIS\&ES). For reference, "Sediment" samples are defined as samples of soil collected from below a permanent surface water body, whether that occurs in a pond, lake or stream, and "Sed/Soil" samples are defined as samples that are not permanently submerged beneath water, but are usually collected directly adjacent to ponds, lakes and streams, characteristically within the floodplain. Descriptions of the data and sampling performed to acquire all of the data by EC\&ACP in support of the FMB, PB, and SC IOUs can be found in separate periodic reports associated with each of these IOUs.

A number of issues related to the use of these data were discussed with the EC\&ACP and SGIS\&ES technical experts and a summary of key points is provided in Section 2.2 Sediment and Sed/Soil Data Processing. EC\&ACP and SGIS\&ES identified the appropriate Sediment and Sed/Soil data associated with FMB, PB, and SC IOUs, extracted that data from the IOU databases and determined which data were valid and appropriate for determining radionuclide inventories for the waterways associated with the three IOUs and transmitted these data to SRNL (see Kubilius email in APPENDIX C). The validated Sediment and Sed/Soil analytical results for all three IOUs combined, were loaded into ArcMap to be segregated spatially, by IOU and by individual IOU sub-compartments. The spatially segregated subsets of analytical data were then used for determination of the representative central tendency of each radionuclide activity level.

\subsection{Development of IOU Compartments}

In the EC\&ACP IOU program, the individual IOUs have been sub-divided into segments (termed subunits) based on factors such as proximity (up-gradient/down-gradient) to contaminant release locations, sub-watershed boundaries, and stream morphology. These subunits, or "compartments", have been documented, described and illustrated in the periodic reports associated with each IOU.

\subsubsection{Fourmile Branch Watershed}

The FMB IOU has been divided into three principal compartments, as indicated in Figure 2-1. The FMB upper compartment delineates a segment of FMB that is upgradient from process facilities and waste areas and is unlikely to have any SRS process discharges or runoff. In addition, this compartment has a narrower and less developed channel and floodplain than the middle and lower reaches of FMB.

The FMB middle compartment received discharges from F- and $\mathrm{H}$-Areas including cooling water, process and sanitary wastewater, and runoff/groundwater releases from waste units, including various spills and releases. Shallow groundwater, contaminated with metals, organics, and radionuclides, discharged at seep locations and adds to the contaminant load that enters FMB. Screening data indicate that Cs-137 is present in contaminated media at this locality with the highest activities located within and adjacent to the FMB channel. Large volumes of water were discharged at high flow rates from C-reactor, located downstream from F- and H-Areas, resulting in transport and deposition of sediment contaminated by radionuclides, metals, and organics along the downstream lengths of FMB. In general, these data indicate that Cs-137 activity is greatest in the FMB channel and floodplain sediment downstream from the General Separations Areas (GSA), in the vicinity of F-Area. The data indicate a trend of generally decreasing activity both in the downstream direction and with depth, suggesting that Cs-137 activity is associated with near-surface sediments. The lower portion of the FMB middle compartment includes Castor 


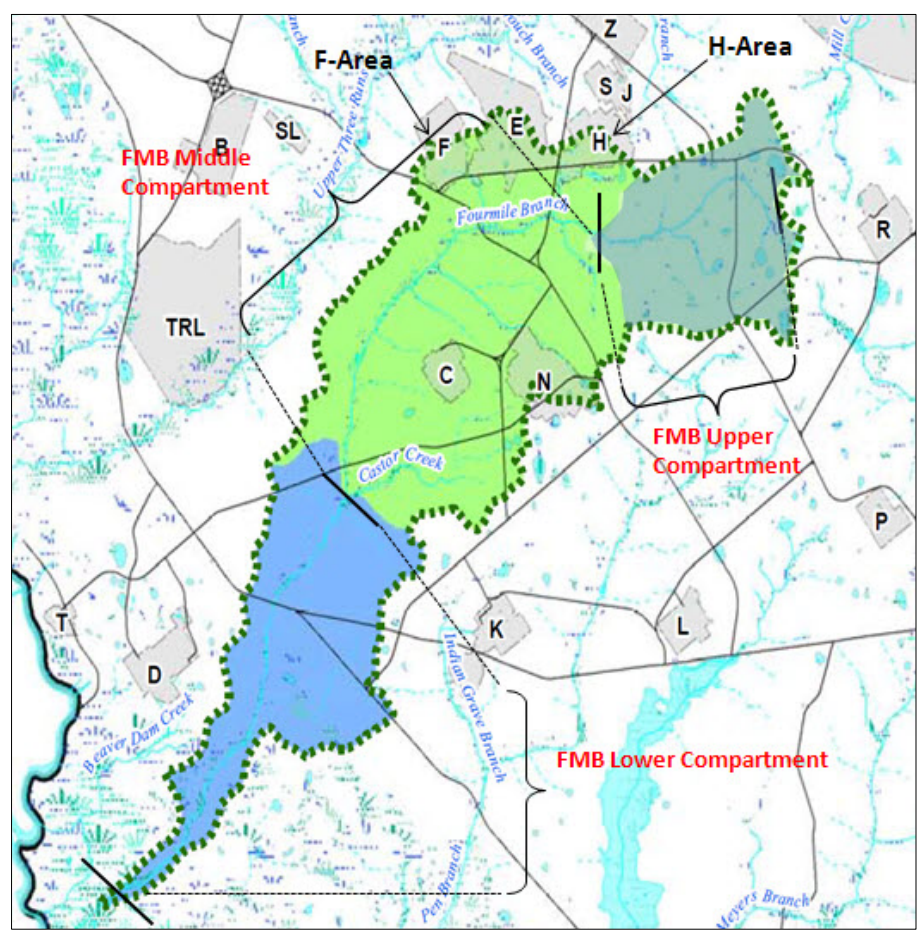

Figure 2-1 Delineation of Fourmile Branch Compartments

Creek/C-Area Reactor Discharge Canal, which is situated on the eastern side of FMB. This portion of FMB received discharges of C-Area Reactor cooling water during its period of operation, resulting in a widening of the original channel and deposition of potentially contaminated sediments in floodplain areas along the portion of FMB adjacent to C-Area and extending further down-gradient into FMB. Reduction of flow rates following the cessation of reactor operations resulted in retreat of the stream, leaving potentially contaminated areas within the floodplain exposed.

The FMB lower compartment extends from just below the confluence of Castor Creek and FMB to the SR. This reach did not receive direct contaminated surface runoff or groundwater discharge from SRS operations, however it is a corridor through which contaminated surface water and sediment migration from upstream has occurred.

For this analysis, the FMB middle compartment was further segregated into five additional subcompartments. These include two areas located adjacent to FMB, one located near F-Area Seepage Basin and the other near H-Area Seepage Basin where grid-like Sed/Soil sampling programs were conducted. These areas are shown in Figure 2-2 with the sample locations (black dots) indicated and a pale blue box; which indicates the size of the region used to calculate the volume and mass of contaminated soil. 


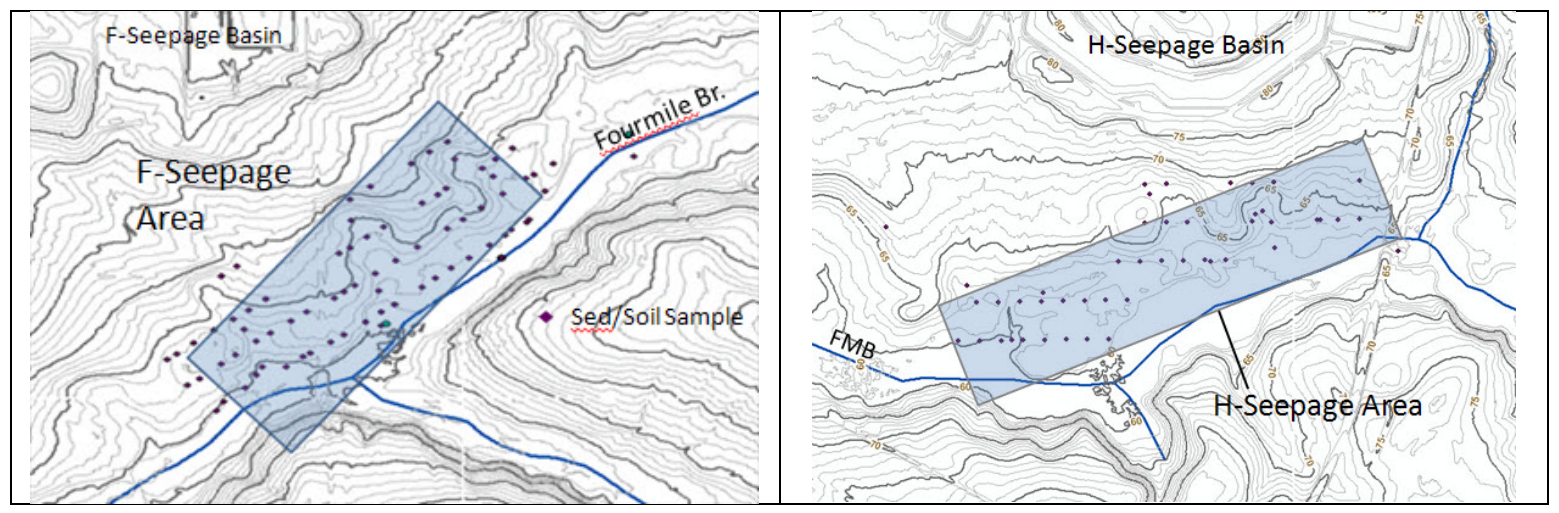

Figure 2-2 Location of the $\mathrm{F}$ - and $\mathrm{H}$ - Seepage areas

Two FMB tributary streams, one originating near F-Area and the other near H-Tank Farm, were also broken out separately because of the potential for contaminated material to exist along their reaches and the presence of Sediment and Sed/Soil samples to characterize the amount of radionuclide activity present. Both sub-compartments are shown in Figure 2-3 with the streams highlighted in a pale blue, transparent overlay, Sed/Soil sample locations indicated with purple diamonds and Sediment sample locations with green dots. Also indicated are the locations of Sed/Soil samples (purple diamonds). Some Sediment samples (green dots) are noted at the headwater diversion ditch on the F-Area tributary. The clusters of Sed/Soil samples at the upper reach of the $\mathrm{H}$-Area tributary reflect a sampling program to characterize/delineate contaminated soil associated with Warner's Pond. These soils have been removed and disposed of within the General Separations Consolidated Unit (i.e., the Old Radioactive Waste Burial Grounds) and are consequently not considered part of the contaminated sources of the FMB IOU.

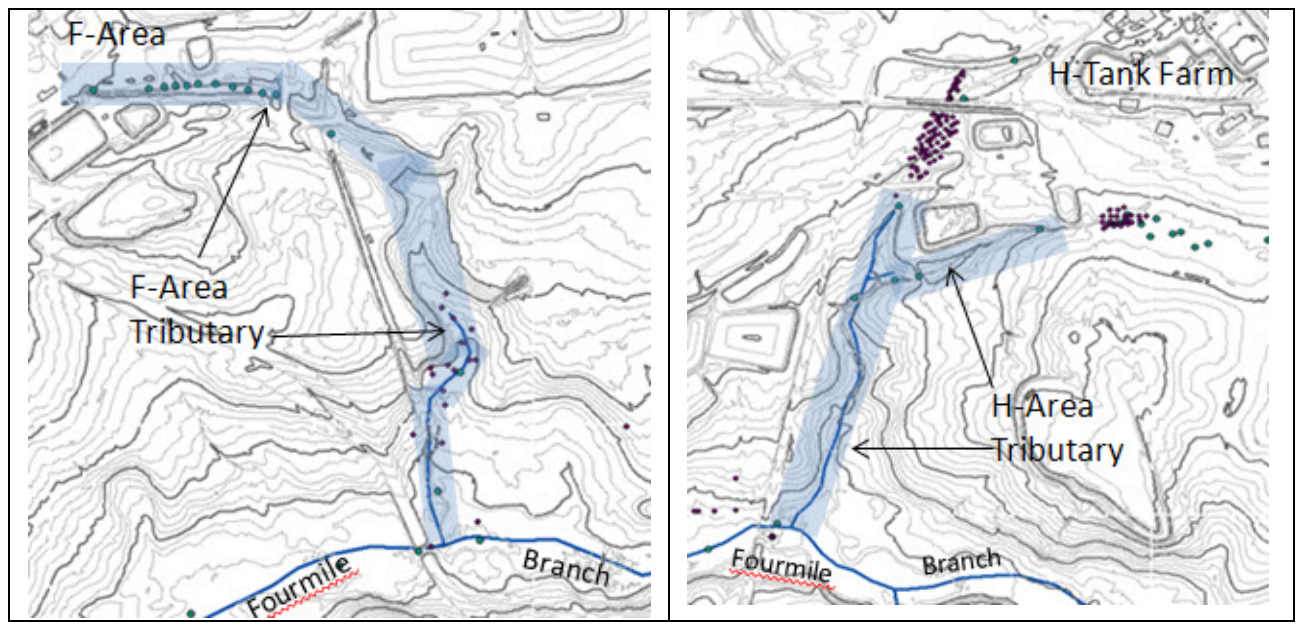

Figure 2-3 Location of F-Area and H-Tank Farm tributaries to FMB

The fifth sub-compartment, the wetlands along Castor Creek, received National Pollutant Discharge Elimination System (NPDES) and process discharges, including cooling water from CReactor (DuPont 1982). The location of Castor Creek is shown in Figure 2-4. 


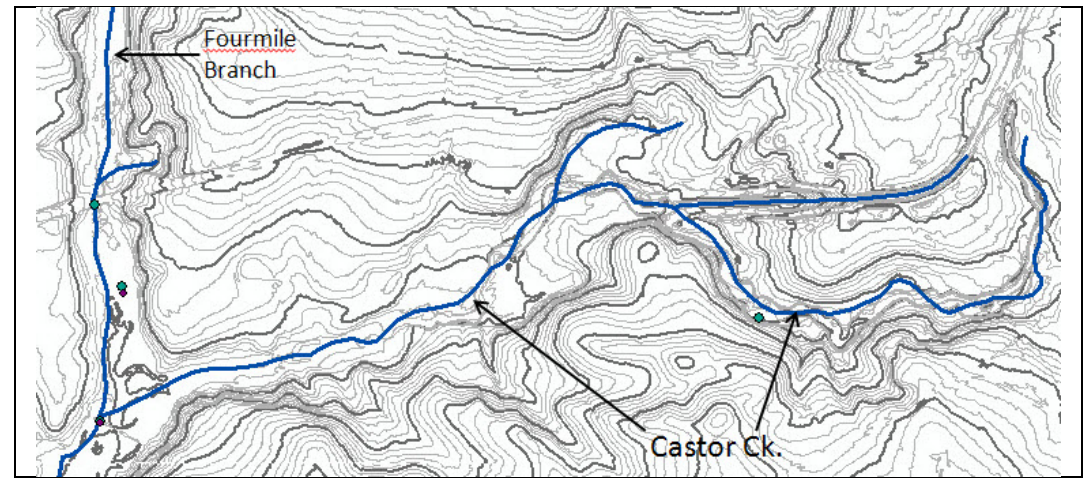

Figure 2-4 Location of Castor Creek.

Additional information can be viewed in the different Periodic Reports for FMB (WSRC 2003, WSRC 2005, and SRNS 2012).

\subsubsection{Pen Branch Watershed}

The conceptual site model (CSM) for the PB IOU divides the watershed into four principal compartments, PB upper, PB middle, Indian Grave Branch, and PB lower, as indicated in Figure 2-5. The PB upper compartment delineates a segment of $P B$ that is upgradient from process facilities and waste areas and is unlikely to have any SRS process discharges or runoff. In addition, this compartment has a narrower and less developed channel and floodplain than the middle and lower reaches of PB.

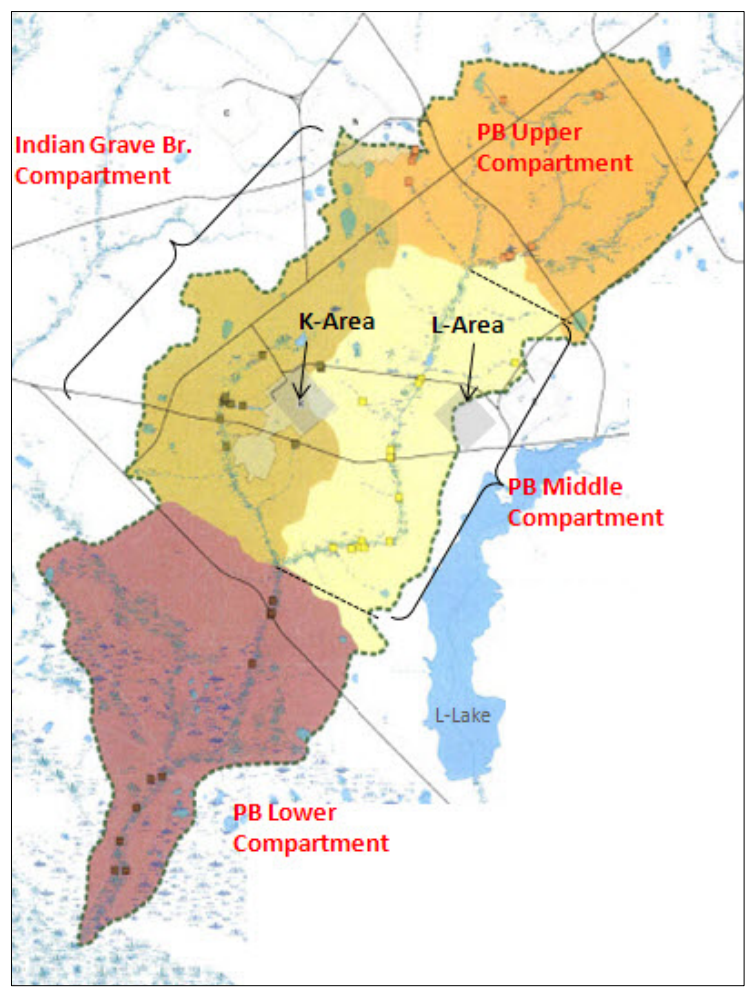

Figure 2-5 Delineation of Pen Branch Compartments 
The PB middle compartment, which extends from the PB upper compartment to the confluence with the Indian Grave Branch, may have received contaminated surface runoff in the vicinity of the L-Area ash basin, from surface water runoff from certain operations, from outfalls in the vicinity of K-Area, and other isolated waste units in the watershed (WSRC 2001).

The Indian Grave Branch compartment is located roughly parallel to the PB middle compartment, both of which encompass K-Area. Indian Grave Branch received potentially contaminated discharges from its upper reaches all the way to its confluence with PB. These include contributions from outfalls, process water from the K-Area discharge canal and potential surface runoff from the ash basin and various waste units (WSRC 2001). Indian Grave Branch and the PB lower compartment received higher volumes of K-Reactor cooling water discharge during the reactor operations period resulting in a widening of the original channel and deposition of contaminated sediments in floodplain areas along these reaches. Reduction of flow rates following the cessation of reactor operations resulted in retreat of the stream, leaving potentially contaminated areas within the floodplain exposed.

The PB lower compartment extends from just below the confluence of Indian Grave Branch, and PB to the SR swamp which eventually discharges into the SR at the mouth of SC. This reach did not receive direct contaminated surface runoff or groundwater discharge from SRS operations, however it is a corridor through which contaminated surface water and sediment migration from upstream has occurred.

Additional information can be viewed in the different Periodic Reports for PB (WSRC 2004a, WSRC 2007, and SRNS 2012).

\subsubsection{Steel Creek Watershed}

The SC IOU has been divided into four principal compartments, as indicated in Figure 2-6. The SC upper compartment delineates a segment of SC that extends from P-Area Reactor Discharge Canal to where SC flows into L-Lake. This segment of SC received reactor cooling water, process water, and contaminated effluent from various releases and spills. The large volumes of water discharged at high flow rates resulted in contaminated sediments beyond the creek channel and into the flood plain (WSRC 2002).

The SC middle compartment includes L-Lake from where SC enters the upstream end of the lake to L-Lake dam. L-Lake (via the L-Area Reactor Discharge Canal) received process and cooling water discharges from P-Reactor via SC and discharges from L-Area units via the L-Area diversion canal.

The SC lower compartment extends from the L-Lake dam to the SR, including the SC delta and lowland floodplain adjacent to the SR that extends to and beyond the SRS boundary. In this investigation, the lower compartment extends downstream approximately $4.2 \mathrm{~km}$ from the confluence of SC and Meyers Branch to the SC delta. The SC delta is where SC enters the SR swamp which forms the transition between the SC delta and the SR swamp prior to discharging into the SR. The SC delta and SR floodplain will be evaluated at a later date. Meyers Branch sits to the east of the main branch of SC and is not known to have received any contaminated 
SRNL-STI-2013-00592

Revision 0

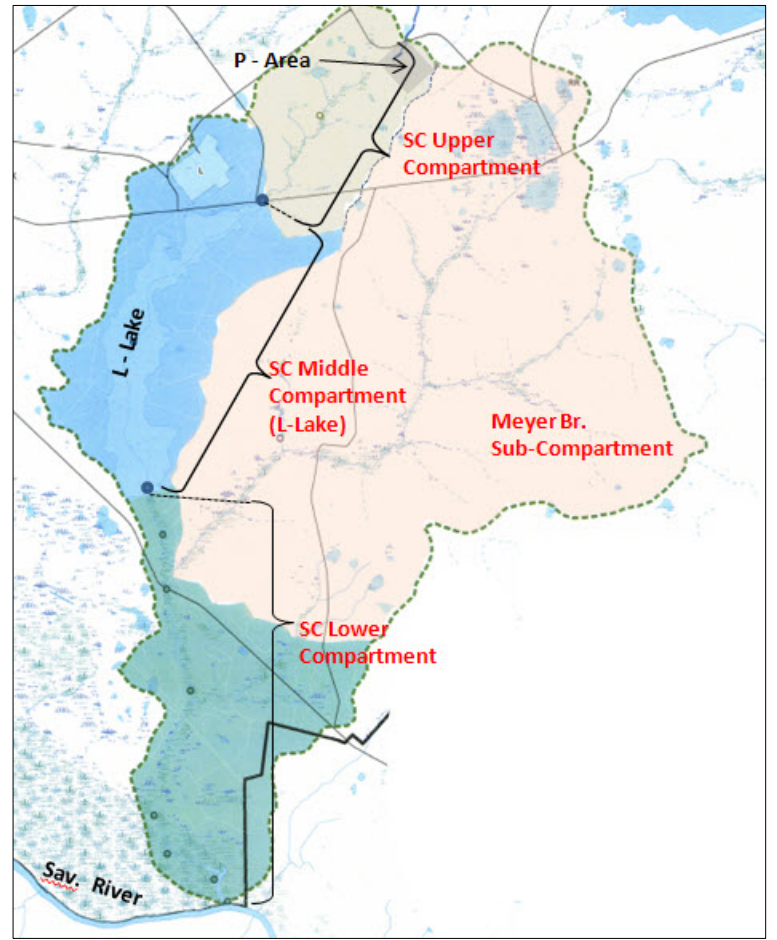

Figure 2-6 Delineation of Steel Creek Compartments

discharges from SRS operations. It is included in this study however, because some Sediment and Sed/Soil samples were collected and evaluated from that portion of the watershed.

Prior to construction of the L-Lake dam in 1985, the creek channel for lower SC received discharges directly from the reactor areas. Higher discharge rates and volumes resulted in a widening of the original channel and deposition of contaminated sediments in floodplain areas. L-Lake was created in 1985, and the reactors were shut down in 1988, decreasing water releases to SC significantly. The reduced flow resulted in retreat of the stream, leaving potentially contaminated areas within the floodplain exposed (WSRC 2002).

Additional information can be viewed in the different Periodic Reports for SC (WSRC 2004b, WSRC 2006 and SRNS 2009).

\subsection{Sediment and Soil/Sediment Data Processing}

As mentioned in Section 2.0, the Sediment and Sed/Soil analytical results provided by EC\&ACP were segregated by IOU compartment within the Geographic Information System (GIS) program ArcMap and then exported into Excel files for processing. Once in Excel, the data for a particular compartment/sub-compartment was further segregated by individual radionuclide within separate worksheets so that a measure of the central tendency of the analytical results for Sediment or Sed/Soil activity concentration (Ci/kg) could be computed for individual compartments.

The radionuclides of interest, for which analyses were performed and whose presence could be confirmed in at least one compartment or sub-compartment of the three IOUs, include the 
following: Am-241, Am-243, C-14, Cs-137, Co-60, Cm-244, Eu-154, I-129, Np-237, Ni-63, Pu238, Pu-239, Pu-242, Sr-90, Tc-99, Th-230, U-234, U-235, and U-238.

In this investigation the laboratory analyses that indicate a result for Sr-89/90, Cm-243/244 and U-233/234 actually reflect activity levels for Sr-90, Cm-244 and U-234, respectively. Justification of this convention was discussed with investigators in EC\&ACP, custodians of the IOU database, and was communicated electronically. (see Kubilius email 8/12/2013 in APPENDIX C).

An important consideration in determining the radionuclide inventory for analytical results is interpreting the data analytical qualifiers associated with individual analyses. The qualifiers /connotations associated with the data evaluated in this report include the following:

$\mathrm{U}$ - species/isotope was analyzed for, but not detected

$\mathrm{J}$ - species/isotope was analyzed for and detected, but the reported value is an estimate

NQ - no qualification is associated with the result

Negative concentrations or activity levels are frequently reported in the analytical results and reflect the condition where the measured result is lower than the long-term background level that has been established for the specific instrument used to make the measurement and, in certain circumstances, are retained for computing representative central values (e.g. mean or median) of the radionuclide. Negative results are qualified as non-detected values (U qualified).

For samples collected within a particular compartment (or sub-compartment) of the FMB, PB, and SC IOUs the following rules apply:

- If the presence of a radionuclide is confirmed in any analytical result ( "J" or "NQ" qualified result), then all other sample results (with exception of lab rejected data) are included in the calculation of the representative central tendency. This would include the values associated with all U-qualified samples, including negative counts results. The rationale is that the $U$ and (-) counts are still the best estimate for that radionuclide in that sample and cannot be censored by elimination from the calculation.

- If all sample results for a particular radionuclide in a particular sub-compartment/subsection have U qualifiers < Method Detection Limit (MDL), then the presence of that radionuclide has not been confirmed and it is presumed to not be present.

The rules and logic described above for selecting data to include in the calculation of the central tendency for Sediment and Sed/Soil samples in individual compartments are based upon the protocol described in Environmental Regulatory Guide for Radiological Effluent Monitoring and Environmental Surveillance (DOE/ER-0173T), which provides guidance for determining measures of central tendency in environmental studies.

A major issue in evaluating the residual radionuclide inventory associated with each IOU compartment is the pervasive lack of data regarding depth interval associated with each Sediment and Sed/Soil sample in the SRS database. This deficiency affects the determination of both the volume and mass of contaminated soil, but also what the central tendency of concentration values might be. This issue was carefully evaluated when the radionuclide inventory was determined for the LTR IOU (SRNL 2012) where sufficient depth information was present to make reasonable assumptions for valid depths of each sample type.

This issue is not as significant for Sediment samples, because there is ample evidence from previous EC\&ACP and SRNL Sediment sampling programs, both in the ponds located on the Pand R-Area canal systems and from samples collected within the main channel of LTR below Par 
Pond Dam to indicate that virtually all of the radionuclide activity is contained within the $0-0.2 \mathrm{~m}$ depth interval. In this investigation of FMB, PB, and SC IOUs, an assumed 0-0.2 m sampling interval is adopted based on that evidence.

With regard to Sed/Soil samples, usually acquired in the floodplain region adjacent to the main channels of SRS streams, the LTR samples had associated depth intervals which provided a basis to make reasonable assumptions. Many of the samples reflect an interval of 0-0.3 m and indicate that the majority of the radionuclide activity is within this interval. Samples collected from the deeper interval from 0.3-1.2 m indicate that some radionuclide activity can occur there but at much lower concentrations than the $0-0.3 \mathrm{~m}$ interval. To account for the small amount of activity associated with the deeper interval, a single representative depth interval of 0-0.35 m was used as a representative depth in the estimation of contaminated soil volumes for the LTR IOU compartments. That assumption is adopted in this investigation to maintain consistency for the FMB, PB, and SC IOU evaluations.

Determination of the central, representative value of the analytical results for each radionuclide in a compartment/sub-compartment in this investigation refers to the computation of the mean or median values. Virtually all of the computed mean values were higher than computed median values. Mean values were selected for use in computing the radionuclide inventories in order to avoid the possibility of under-estimating the actual radionuclide inventory for a given compartment/sub-compartment. There were a couple of instances in which the mean activity value for all analyses of a particular radionuclide was computed to be a negative number. In those cases the median value was used as the representative central value, instead.

The Sediment and Sed/Soil samples utilized in this investigation were collected on different dates. Many samples are much older than more recently acquired samples. To address this disparity, the analytical results, with the exception of Am-241, were decay corrected to September, 2013. This process is particularly important to assess radionuclides with relatively short half-lives, like Cs137.

The presence of Am-241 in the SRS IOUs is not the result of direct release of that radionuclide from DOE operations, but rather occurs as in-growth from the decay of a very small amount of $\mathrm{Pu}-241$ that is apparently present in the Sediment and Sed/Soil. Thus, in this analysis it was not appropriate to decay Am-241 to September 2013. In this investigation, the actual laboratory results are used directly to estimate the current concentration of Am-241.

The presence of U-234, U-235, and U-238 in the FMB, PB, and SC IOUs are a mixture of natural uranium and DOE-added uranium but are dominated by natural uranium. Sediment and Sed/Soil representative central tendency values for each IOU compartment were compared to two times the R-Area uranium background values (1.55 pCi/g for U-233/234, $0.078 \mathrm{pCi} / \mathrm{g}$ for U-235, and $1.4 \mathrm{pCi} / \mathrm{g}$ for U-238). The background levels are reported in WSRC 2002. The majority of FMB, $\mathrm{PB}$, and SC compartments have concentrations less than these background numbers, suggesting that DOE added uranium was not a significant contributor. Only FMB and SC IOUs contained any DOE-added uranium which occurred in the FMB Middle compartment and the SC upper compartment. More specifically, in FMB, the DOE added uranium occurred in the Middle compartment channel sediment, the F-Area tributary sediment, the Middle compartment Sed/Soil, and the F-Area Seepage zone Sed/Soil. The DOE-added inventory was computed by subtracting the R-Area background isotope concentration from the computed representative central value of the same isotope for each of these compartments and converting that into an inventory. 
Similarly to the uranium isotopes, Th-230 also occurs naturally and therefore is not considered to be present as DOE added in FMB, PB, and SC IOU compartments unless the representative central value is greater than the threshold of $1.4 \mathrm{pCi} / \mathrm{g}$. This value was the consensus value agreed upon by several SRNL scientists (see Meeting Minutes in APPENDIX C). The presence of Th230 was dominated by the natural form but DOE-added Th-230 was found in FMB Middle Sed/Soil and in the SC Upper compartment Sediment and Sed/Soil. The DOE-added component of Th-230 activity was computed in the same fashion as described for the uranium isotopes.

APPENDIX A, Sediment and Sed/Soil Analytical data for FMB, PB, and SC IOU SubCompartments, provides the number of sample results and number of "less than detect" results associated with each radionuclide in each compartment, the central, representative concentration value for each radionuclide, and the computed inventory for Sediment and Sed/Soil sample types within each compartment.

\subsection{Estimating the Mass of Contaminated Sediment and Sed/Soil}

Once the radionuclide activity levels (central tendencies) were determined for the FMB, PB, and SC IOU compartment/sub-compartment, the mass of contaminated media associated with each sub-compartment/sub-section was estimated.

The calculation was performed using estimates for the following geometric parameters and material properties.

- Representative length

- Representative width

- Representative depth of the Sediment or Sed/Soil sample set

- Representative area for L-Lake

- Representative bulk density of the Sediment and Soil/sediment

The representative length and width for Sediment and Sed/Soil zones within each compartment of the FMB, PB, and SC IOUs were estimated using the Measuring tool within ArcMap and careful examination of the Light Detection and Ranging (LIDAR) land surface contour coverage within the ArcMap project. An average of multiple width estimates along each reach was utilized. The ArcMap measurement tool was also used to estimate the length of compartments or subcompartments within the IOUs. As mentioned earlier, the representative sample depths associated with Sediment (submerged) samples and Sed/Soil (non-submerged) samples were established as 0.2 and $0.35 \mathrm{~m}$, respectively. Using these representative lengths, widths, and depths, the volume of contaminated material was computed and then converted to a mass, using a representative bulk density of the sediment material. The relevant geometric information for compartments and subcompartments within FMB, PB, and SC IOU and for L-Lake is presented in APPENDIX B, FMB, $P B$, and SC IOU Compartment/Sub-Compartment Dimensions and Computation of Contaminated Soil Volume and Mass.

Once the mass $(\mathrm{kg})$ of contaminated media was determined for each compartment/subcompartment, the inventory (in $\mathrm{Ci}$ ) for each radionuclide could be estimated using the representative central radionuclide concentration values (e.g. Ci $/ \mathrm{kg}$ ) for both Sediment and Sed/Soil sample sets associated with each sub-compartment. As indicated in Section 2.2, all of 
the data used to calculate the representative central values (except for Am-241) have been decayed corrected from the date of the sample analysis to September, 2013 in order to standardize all measurements to a single date and to provide the most accurate estimate of the remaining radionuclide activity in the FMB, PB, and SC IOUs as possible.

The key email that accompanied the transmittal of the screened Sediment and Sed/Soil data from EC\&ACP to SRNL is cited in Section 2.2 and presented in APPENDIX C, Email Correspondence and Meeting Notes, in addition to appearing in Section 4.0 References. This email discusses certain screening criteria that were applied, clarifies certain terms that are used in the database, provides an explanation of comments that are provided for certain data, documents where modifications were made to the IOU database entries, and explains why the changes were made, and identified those radionuclides that go by more than one name and suggested the preferred one.

A potentially important factor exists in the PB IOU in that no Sed/Soil analytical results appropriate for calculating radionuclide inventories exist along the floodplain of PB. In all of the IOUs that received elevated reactor cooling water return flows, residual quantities of radionuclides were deposited on sediments in the floodplains immediately adjacent to the main stream channels. In the other IOUs, it appears that the majority of the remaining radionuclide activity resides in these sediments. Consequently, an alternative approach was employed to estimate the residual radionuclide activity in PB floodplain sediments.

Two separate methods were employed to estimate the floodplain component of the PB radionuclide inventory, both drew upon information that was available from the adjacent SC and LTR IOUs. The first method utilized the ratio of Cs-137 total inventory associated with the floodplain (Sed/Soil samples) for a given IOU compartment to the stream channel (Sediment samples) Cs-137 total activity in the same compartment. The second method drew upon the ratio of Cs-137 total inventory associated with the floodplain (Sed/Soil) in an IOU versus the total estimated release of Cs-137 into the IOU.

The first method utilized a nominal ratio of 100:1 for Sed/Soil Cs-137 total activity to Sediment Cs-137 total activity based on the range of ratios obtained from two SC IOU and three LTR IOU compartments. The ratios ranged from 38.8:1 to 241:1 with an average value of 48:1. The combined total Cs-137 inventory for Indian Grave Br. and PB lower reach was $1.45 \mathrm{Ci}$. The use of this 100:1 ratio is thought to introduce a slight overestimation of radionuclide activity.

The second method utilized a ratio of current estimate of total residual Cs-137 activity in the SC IOU (17.7 Ci) to the total Cs-137 released to SC during SRS reactor operations period (285 Ci). The computed ratio of $17.4 / 285=0.061$ was applied to $\mathrm{PB}$, where the estimated total release of Cs-137 was reported to be $24.6 \mathrm{Ci}$. The resulting floodplain inventory was thus computed to be $0.061 * 24.6-(0.0134+0.00108+0.00102+0.0011)=1.49 \mathrm{Ci}$, where the terms in parenthesis are the Sediment components of Cs-137 activity in the different PB compartments.

An average of the two estimates (e.g. $(1.49+1.45) / 2=1.47 \mathrm{Ci})$ was computed to represent the Cs-137 total activity in PB. With regard to the other radionuclides detected in PB Sediment sample analyses, the 100:1 Sed/Soil to Sediment activity ratio was utilized to compute the total activity for each. 


\subsection{Quality Assurance}

Requirements for performing reviews of technical reports and the extent of review are established in manual E7 2.60. SRNL documents the extent and type of review using the SRNL Technical Report Design Checklist contained in WSRC-IM-2002-00011, Rev. 2.

Many of the issues presented in Section 2.2 and Section 2.3 were discussed at a meeting by SRNL and EC\&ACP investigators prior to processing the FMB, PB, and SC data to agree upon key protocol for the radionuclide inventory analysis. The minutes of that meeting are presented in an email within APPENDIX C, Email Correspondence and Meeting Notes.

\subsection{Results}

Using the method described in Section 2.0, the September 2013 radionuclide inventories for each sub-compartments associated with each of the three IOUs were computed, by radionuclide. These estimates are presented in Tables 3-1 through 3-3. The inventories for each of the IOU compartments are rolled-up into a total radionuclide inventory for the each IOU in Table 3-4.

Table 3-1 Summary of Radionuclide Inventories for FMB IOU Compartments

\begin{tabular}{|c|c|c|c|c|c|c|c|c|}
\hline Nuclide & $\begin{array}{c}\text { FMB } \\
\text { Lower } \\
\text { Sediment } \\
\text { Mean } \\
\text { (Ci) }\end{array}$ & $\begin{array}{c}\text { FMB } \\
\text { Lower } \\
\text { Sed/Soil } \\
\text { Mean } \\
\text { (Ci) }\end{array}$ & $\begin{array}{c}\text { FMB } \\
\text { Middle } \\
\text { Sediment } \\
\text { Mean } \\
\text { (Ci) }\end{array}$ & $\begin{array}{c}\text { FMB } \\
\text { Middle } \\
\text { Sed/Soil } \\
\text { Mean } \\
\text { (Ci) }\end{array}$ & $\begin{array}{c}\text { FMB } \\
\text { Upper } \\
\text { Sediment } \\
\text { Mean } \\
\text { (Ci) }\end{array}$ & $\begin{array}{c}\text { FMB } \\
\text { Upper } \\
\text { Sed/Soil } \\
\text { Mean } \\
\text { (Ci) }\end{array}$ & $\begin{array}{c}\text { FMB } \\
\text { Castor } \\
\text { Creek } \\
\text { Sediment } \\
\text { Mean } \\
\text { (Ci) }\end{array}$ & $\begin{array}{c}\text { FMB } \\
\text { Castor } \\
\text { Creek } \\
\text { Sed/Soil } \\
\text { Mean } \\
\text { (Ci) }\end{array}$ \\
\hline Am-241 & $1.94 \mathrm{E}-03$ & --- & 6.13E-03 & $4.45 \mathrm{E}-01$ & --- & --- & --- & --- \\
\hline Am-243 & --- & --- & $2.00 \mathrm{E}-03$ & 1.88E-01 & --- & --- & --- & --- \\
\hline C-14 & --- & --- & $1.14 \mathrm{E}-04$ & 6.92E-04 & --- & --- & --- & --- \\
\hline Cs-137 & $1.03 \mathrm{E}-01$ & $1.71 \mathrm{E}+00$ & 3.41E-01 & $6.98 \mathrm{E}+00$ & $2.44 \mathrm{E}-04$ & $8.66 \mathrm{E}-04$ & $2.06 \mathrm{E}-04$ & --- \\
\hline Co-60 & $1.81 \mathrm{E}-03$ & 1.89E-02 & $4.23 \mathrm{E}-04$ & 7.24E-02 & --- & --- & --- & --- \\
\hline Cm-244 & 4.38E-04 & 9.09E-03 & 3.71E-03 & 4.49E-01 & --- & --- & --- & --- \\
\hline Eu-154 & --- & --- & --- & $1.66 \mathrm{E}-02$ & --- & --- & --- & --- \\
\hline I-129 & $2.16 \mathrm{E}-03$ & --- & $9.36 \mathrm{E}-03$ & $4.50 \mathrm{E}+00$ & --- & --- & --- & --- \\
\hline $\mathrm{Np}-237$ & $1.05 \mathrm{E}-04$ & --- & 3.99E-04 & 6.20E-02 & --- & --- & --- & --- \\
\hline Ni-63 & --- & --- & $1.84 \mathrm{E}-02$ & $2.06 \mathrm{E}-01$ & --- & --- & --- & --- \\
\hline Pu-238 & 4.00E-04 & 4.17E-03 & $1.08 \mathrm{E}-02$ & 1.81E-01 & --- & 1.49E-05 & --- & --- \\
\hline Pu-239 & $3.21 \mathrm{E}-04$ & 7.47E-03 & 2.31E-03 & $6.23 \mathrm{E}-02$ & --- & $6.95 \mathrm{E}-05$ & --- & --- \\
\hline Sr-90 & 9.90E-03 & 2.83E-02 & 8.84E-03 & $3.12 \mathrm{E}+00$ & $5.40 \mathrm{E}-03$ & 9.19E-04 & --- & --- \\
\hline Tc-99 & 3.87E-03 & --- & $5.10 \mathrm{E}-02$ & $3.41 E+00$ & --- & --- & --- & --- \\
\hline Th-230 & --- & --- & --- & 3.85E-02 & --- & --- & --- & --- \\
\hline U-234 & --- & --- & $1.12 \mathrm{E}-02$ & $4.14 \mathrm{E}+00$ & --- & --- & --- & --- \\
\hline U-235 & --- & --- & 2.32E-03 & 3.71E-01 & --- & --- & --- & --- \\
\hline U-238 & --- & --- & 2.27E-02 & $5.44 \mathrm{E}+00$ & --- & --- & --- & --- \\
\hline
\end{tabular}

Note: the symbol -- means the sample analyses cannot confirm that the particular radionuclide is present 
Table 3-2 Summary of Radionuclide Inventories for the Pen Branch IOU

\begin{tabular}{|c|c|c|c|c|c|c|c|c|}
\hline Nuclide & $\begin{array}{c}\text { PB } \\
\text { Lower } \\
\text { Sediment } \\
\text { Mean } \\
\text { (Ci) }\end{array}$ & $\begin{array}{c}\text { PB } \\
\text { Lower } \\
\text { Sed/Soil } \\
\text { Mean } \\
\text { (Ci) }\end{array}$ & $\begin{array}{c}\text { PB } \\
\text { Middle } \\
\text { Sediment } \\
\text { Mean } \\
\text { (Ci) }\end{array}$ & $\begin{array}{c}\text { PB } \\
\text { Middle } \\
\text { Sed/Soil } \\
\text { Mean } \\
\text { (Ci) }\end{array}$ & $\begin{array}{c}\text { PB } \\
\text { Upper } \\
\text { Sediment } \\
\text { Mean } \\
\text { (Ci) }\end{array}$ & $\begin{array}{c}\text { PB } \\
\text { Upper } \\
\text { Sed/Soil } \\
\text { Mean } \\
\text { (Ci) }\end{array}$ & $\begin{array}{c}\text { PB } \\
\text { Indian } \\
\text { Grave Br } \\
\text { Sediment } \\
\text { Mean } \\
\text { (Ci) }\end{array}$ & $\begin{array}{c}\text { PB } \\
\text { Indian } \\
\text { Grave Br } \\
\text { Sed/Soil } \\
\text { Mean } \\
\text { (Ci) }\end{array}$ \\
\hline Cs-137 & $1.34 \mathrm{E}-02$ & $1.20 \mathrm{E}+00$ & $1.08 \mathrm{E}-03$ & $9.67 \mathrm{E}-02$ & $1.02 \mathrm{E}-03$ & $9.08 \mathrm{E}-02$ & $1.10 \mathrm{E}-03$ & $9.79 \mathrm{E}-02$ \\
\hline Co-60 & $6.02 \mathrm{E}-04$ & 5.37E-02 & & -- & -- & -- & 7.37E-05 & $6.57 \mathrm{E}-03$ \\
\hline Cm-244 & $5.18 \mathrm{E}-06$ & $4.62 \mathrm{E}-04$ & $1.35 \mathrm{E}-05$ & $1.20 \mathrm{E}-03$ & -- & -- & -- & -- \\
\hline I-129 & 1.37E-03 & $1.22 \mathrm{E}-01$ & -- & -- & -- & -- & -- & -- \\
\hline $\mathrm{Pu}-238$ & $2.60 \mathrm{E}-05$ & $2.31 \mathrm{E}-03$ & -- & -- & -- & -- & $1.68 \mathrm{E}-05$ & $1.50 \mathrm{E}-03$ \\
\hline Pu-239 & $8.75 \mathrm{E}-05$ & $7.80 \mathrm{E}-03$ & $1.22 \mathrm{E}-05$ & $1.09 \mathrm{E}-03$ & -- & -- & $8.47 \mathrm{E}-05$ & $7.55 \mathrm{E}-03$ \\
\hline $\mathrm{Pu}-242$ & -- & -- & $1.48 \mathrm{E}-02$ & $1.32 \mathrm{E}+00$ & 7.53E-03 & 6.72E-01 & -- & -- \\
\hline Sr-90 & $2.10 \mathrm{E}-04$ & $1.87 \mathrm{E}-02$ & -- & -- & -- & -- & -- & -- \\
\hline Tc-99 & $1.08 \mathrm{E}-03$ & 9.63E-02 & -- & -- & -- & -- & -- & -- \\
\hline
\end{tabular}

Note: the symbol -- means the sample analyses cannot confirm that the particular radionuclide is present

Table 3-3 Summary of Radionuclide Inventories for SC IOU

\begin{tabular}{|c|c|c|c|c|c|c|c|c|}
\hline Nuclide & $\begin{array}{c}\text { SC Lower } \\
\text { Sediment } \\
\text { Mean } \\
\text { (Ci) }\end{array}$ & $\begin{array}{c}\text { SC } \\
\text { Lower } \\
\text { Sed/Soil } \\
\text { Mean } \\
\text { (Ci) }\end{array}$ & $\begin{array}{c}\text { SC } \\
\text { L-Lake } \\
\text { Sediment } \\
\text { Mean } \\
\text { (Ci) }\end{array}$ & $\begin{array}{c}\text { SC } \\
\text { L-Lake } \\
\text { Sed/Soil } \\
\text { Mean } \\
\text { (Ci) }\end{array}$ & $\begin{array}{c}\text { SC } \\
\text { Upper } \\
\text { Sediment } \\
\text { Mean } \\
\text { (Ci) }\end{array}$ & $\begin{array}{c}\text { SC } \\
\text { Upper } \\
\text { Sed/Soil } \\
\text { Mean } \\
\text { (Ci) }\end{array}$ & $\begin{array}{c}\text { SC } \\
\text { Meyers } \\
\text { Br } \\
\text { Sediment } \\
\text { Mean } \\
\text { (Ci) }\end{array}$ & $\begin{array}{c}\text { SC } \\
\text { Meyers } \\
\text { Br } \\
\text { Sed/Soil } \\
\text { Mean } \\
\text { (Ci) }\end{array}$ \\
\hline Am-241 & $1.44 \mathrm{E}-04$ & -- & -- & -- & $1.01 \mathrm{E}-04$ & -- & -- & -- \\
\hline C-14 & -- & -- & -- & -- & $2.80 \mathrm{E}-03$ & -- & -- & -- \\
\hline Cs-137 & $2.87 \mathrm{E}-02$ & $9.62 \mathrm{E}+00$ & $3.75 E+00$ & -- & 9.97E-02 & $3.90 \mathrm{E}+00$ & $2.54 \mathrm{E}-04$ & $1.54 \mathrm{E}-03$ \\
\hline Co-60 & $9.04 \mathrm{E}-05$ & 6.07E-02 & 8.50E-03 & -- & 6.64E-05 & $1.21 \mathrm{E}-03$ & -- & -- \\
\hline Cm-244 & $2.42 \mathrm{E}-06$ & -- & -- & -- & 8.59E-03 & -- & -- & -- \\
\hline Np-237 & -- & 2.52E-01 & -- & -- & -- & -- & -- & -- \\
\hline Ni-63 & -- & -- & -- & -- & $8.87 \mathrm{E}-03$ & $1.78 \mathrm{E}-01$ & -- & -- \\
\hline $\mathrm{Pu}-238$ & $1.30 \mathrm{E}-04$ & 7.19E-03 & $4.08 \mathrm{E}-02$ & -- & $0.00+00^{1}$ & $1.22 \mathrm{E}-02$ & -- & -- \\
\hline $\mathrm{Pu}-239$ & $1.19 \mathrm{E}-04$ & $9.04 \mathrm{E}-03$ & $3.71 \mathrm{E}-02$ & -- & 3.81E-05 & $6.86 \mathrm{E}-03$ & $8.31 \mathrm{E}-05$ & -- \\
\hline Sr-90 & $1.16 \mathrm{E}-03$ & 4.84E-02 & 3.01E-01 & -- & $1.55 \mathrm{E}-04$ & $2.49 \mathrm{E}-02$ & $1.11 \mathrm{E}-03$ & -- \\
\hline Tc-99 & -- & -- & -- & -- & 6.59E-03 & -- & -- & -- \\
\hline Th-230 & -- & -- & -- & -- & $2.08 \mathrm{E}-03$ & $9.47 \mathrm{E}-02$ & -- & -- \\
\hline U-234 & -- & -- & -- & -- & -- & $4.03 \mathrm{E}-02$ & -- & -- \\
\hline U-235 & -- & -- & -- & -- & -- & $3.01 \mathrm{E}-03$ & -- & -- \\
\hline U-238 & -- & -- & -- & -- & -- & $4.00 \mathrm{E}-02$ & -- & -- \\
\hline
\end{tabular}

Note: the symbol -- means the sample analyses cannot confirm that the particular radionuclide is present

${ }^{1}$ Median was used instead of Mean value 
Table 3-4 Radionuclide Total Inventory Roll-up for FMB IOU, PB IOU and SC IOU

\begin{tabular}{|c|c|c|c|}
\hline Nuclide & FMB IOU (Ci) & PB IOU (Ci) & SC IOU (Ci) \\
\hline Am-241 & $4.54 \mathrm{E}-01$ & -- & $2.45 \mathrm{E}-04$ \\
\hline Am-243 & $1.90 \mathrm{E}-01$ & -- & -- \\
\hline C-14 & $8.07 \mathrm{E}-04$ & -- & $2.80 \mathrm{E}-03$ \\
\hline Cs-137 & $9.13 \mathrm{E}+00$ & $1.50 \mathrm{E}+00$ & $1.74 \mathrm{E}+01$ \\
\hline Co-60 & $9.36 \mathrm{E}-02$ & $6.09 \mathrm{E}-02$ & $7.05 \mathrm{E}-02$ \\
\hline Cm-244 & $4.63 \mathrm{E}-01$ & $1.69 \mathrm{E}-03$ & $8.59 \mathrm{E}-03$ \\
\hline Eu-154 & $1.66 \mathrm{E}-02$ & -- & -- \\
\hline I-129 & $4.51 \mathrm{E}+00$ & $1.23 \mathrm{E}-01$ & -- \\
\hline Np-237 & $6.25 \mathrm{E}-02$ & -- & $1.87 \mathrm{E}-01$ \\
\hline Ni-63 & $2.24 \mathrm{E}-01$ & -- & $6.03 \mathrm{E}-02$ \\
\hline Pu-238 & $1.97 \mathrm{E}-01$ & $3.85 \mathrm{E}-03$ & $5.32 \mathrm{E}-02$ \\
\hline Pu-239 & $7.28 \mathrm{E}-02$ & $1.66 \mathrm{E}-02$ & -- \\
\hline Pu-242 & -- & $2.01 \mathrm{E}+00$ & $3.77 \mathrm{E}-01$ \\
\hline Sr-90 & $3.17 \mathrm{E}+00$ & $1.89 \mathrm{E}-02$ & $6.59 \mathrm{E}-03$ \\
\hline Tc-99 & $3.46 \mathrm{E}+00$ & $9.74 \mathrm{E}-02$ & $9.68 \mathrm{E}-02$ \\
\hline Th-230 & $3.85 \mathrm{E}-02$ & -- & $4.03 \mathrm{E}-02$ \\
\hline U-234 & $4.15 \mathrm{E}+00$ & -- & $3.01 \mathrm{E}-03$ \\
\hline U-235 & $3.74 \mathrm{E}-01$ & -- & $4.00 \mathrm{E}-02$ \\
\hline U-238 & $5.46 \mathrm{E}+00$ & -- & \\
\hline
\end{tabular}

To put the computed estimate of radionuclide activities within FMB, PB, and SC IOUs into context, attention was drawn to Cs-137, which was the radionuclide with the largest contributor to the calculated dose to a member of the public at the perimeter of SRS within the 2010 SRS CA (SRNL 2010). Previous estimates of Cs-137 for these IOUs are summarized in Table 3-5.

Table 3-5 Previously Reported Cs-137 Inventories for FMB, PB, and SC IOUs

\begin{tabular}{|c|c|c|c|c|c|c|}
\hline $\begin{array}{l}\text { SRS } \\
\text { Stream }\end{array}$ & $\begin{array}{c}\text { Cs-137 } \\
\text { Total } \\
\text { Release to } \\
\text { Stream } \\
\text { from } 1954 \\
\text { to } 2010^{1} \\
\text { (Ci) }\end{array}$ & $\begin{array}{c}\text { Total } \\
\text { Release } \\
\text { Decay } \\
\text { Corrected } \\
\text { to } 2013 \\
\text { (Ci) }\end{array}$ & $\begin{array}{c}1985 \\
\text { Cs-137 } \\
\text { Stream } \\
\text { Inventory } \\
\text { Estimate } \\
\text { (Ci) }\end{array}$ & $\begin{array}{c}1985 \\
\text { Inventory } \\
\text { Estimates } \\
\text { Decay } \\
\text { Corrected } \\
\text { to } 2013 \\
\text { (Ci) }\end{array}$ & $\begin{array}{c}2010 \text { SRS } \\
\text { CA } \\
\text { Inventory } \\
\text { from Table } \\
\text { A-77 } \\
\text { (Ci) }\end{array}$ & $\begin{array}{c}\text { Current } \\
\text { Investigation } \\
\text { Cs-137 } \\
\text { Inventory } \\
\text { Estimate } \\
\text { (Ci) }\end{array}$ \\
\hline FMB & 77.7 & 27.8 & $40^{2}$ & 21 & 154 & 9.13 \\
\hline $\mathrm{PB}$ & 24.6 & 7.78 & $11.4^{2}$ & 5.99 & 13 & 1.50 \\
\hline SC & 285 & 95.9 & $44^{3}$ & 21.1 & 120 & 17.4 \\
\hline
\end{tabular}

${ }^{1}$ Carlton et al. 1992 and Annual Environmental Report Data through 2010

2 Gladden, 1985; ${ }^{3}$ DOE EIS 0108, 1982; ${ }^{4}$ SRNL 2010

The first inventory estimate provided in Table 3-5 is an estimate of historical Cs-137 releases to each of the streams from SRS operations based upon concentration and discharge volume measurements (Carlton et. al. 1992 and SRS Annual Environmental Report Data through 2010). These total release estimates were decayed to the present time to provide a bounding estimate of Cs-137 activity that could possibly remain in the SRS streams not accounting for water or sediment transport of Cs-137 out of the stream. 
A second inventory estimate provided in Table 3-5 (Gladden et. al. 1985) computed the residual Cs-137 in SRS streams (FMB, and PB) by taking the calculated SRS total operational releases of Cs-137 to SRS streams from 1960 to 1978, then subtracting an estimate of Cs-137 activity discharged from SRS into the SR during the same time period and then apportioned the remaining Cs-137 activity to each SRS stream based upon the percentage of the estimated total Cs-137 discharged by SRS operations into each stream. Prior to 1960, Cs-137 was not measured in SRS streams because technology to routinely monitor it did not exist. After 1960 the advent of routine gamma spectrometry, liquid scintillation counting, and low-level beta counting combined with automation of counting equipment and data reduction by computer, routine identification and monitoring of specific radionuclides became possible Du Pont, 1982a). The FMB, and PB estimated Cs-137 results were decayed from 1985 to 2013 for use in comparing them to the results of this investigation. The Gladden et.al.1985 report cites a method for computing Cs-137 inventories in the SRS stream corridors IOUs that is not fully explained. Specifically, the documentation refers to the use of SR Cs-137 activity estimates obtained in SR, upstream and downstream from SRS to infer how much Cs-137 was retained within SRS stream corridors, but does not indicate how those estimates were calculated. Those estimates apparently relied on estimates of SR flow rates coupled with the use of analyses of water samples collected at the same locations in SR, to determine the amount of Cs-137 exported from SRS to the SR, therefore allowing a determination of how much Cs-137 was retained within SRS stream corridors. That method produced residual Cs-137 activities retained in SRS stream corridor sediments that are a high percentage (75-85\%) of the cumulative Cs-137 activity released into those streams over the years

A third inventory estimate provided in Table 3-5 (DOE EIS 0108) computed the residual Cs-137 in SC whereby the residual Cs-137 activity was computed for the different reaches of SC based on a soil core sampling program. These soil cores were collected and analyzed in 1981, providing the basis for a dependable estimate of residual Cs-137 in SC reaches. This estimate for SC, when decayed to 2013 conforms closely with the current estimate, which is based on more recent soil core information.

The 2010 SRS CA (SRNL 2010) cited the Cs-137 inventory in each of the SRS IOUs. The methodology used as the basis for those estimates is not documented but is thought to have been related to the use of Sediment and Sed/Soil analytical results in conjunction with estimating the amount of contaminated material in each IOU. Cs-137 is the only IOU contaminant of concern identified in this report because it is the radionuclide of any consequence in terms of delivering a dose to an offsite member of the public. These Cs-137 activity estimates all appear to be too high and in reality should be superseded by subsequent IOU radionuclide total activity estimates currently being developed. The prior, albeit elevated, total activity estimates can serve to provide context for evaluating potential doses to an offsite member of the public. When the elevated estimates were incorporated into the CA contaminant transport and dose model, the highest computed dose to an offsite member of the public was $3 \mathrm{mrem} / \mathrm{yr}$., which is one-tenth of the administrative dose constraint of $30 \mathrm{mrem} / \mathrm{yr}$.

The method employed in this investigation attempts to directly evaluate only the radionuclide contamination that remains within the stream corridors, by use of relatively recent Sediment and Sed/Soil sample and screening out analytical data obtained using less dependable laboratory methods and estimating the volume and mass of contaminated sediment and soil in the stream corridors. Using Cs-137 activity estimates based on this method to compare this approach to previous approaches, this method produced Cs-137 activity estimates that range from $19-33 \%$ of the Cs-137 activity originally released to the SRS streams. This lower percentage of the 
discharged Cs-137 activity actually adsorbing onto stream and floodplain sediments seems more plausible because the actual Cs-137 releases in the three IOUs occurred in conjunction with the release of reactor cooling water at high discharge rates into the headwaters of the streams.

Consequently, it is thought that evaluating radionuclide residual activity based on the collection of soil core information, analytical laboratory results of that material and an estimate of the mass and volume of the contaminated material is the preferred approach for calculating the residual radionuclide activities. It is significant to note the close correspondence of the Cs-137 inventory estimate derived from the decay-corrected DOE EIS 0108 estimate in the SC corridor with the independently computed estimate in this investigation. Both estimates relied upon soil cores acquired in the stream and in the floodplain along the stream corridor.

It was mentioned in Section 2.3 that due to the absence of validated Sed/Soil sample results to quantify the residual radionuclide inventory in the PB floodplain sediments, a ratio that related the Cs-137 Sediment inventory for a particular IOU compartment to Sed/Soil inventory for the same compartment was calculated. Two approaches were employed to estimate the Cs-137 residual activity remaining in the floodplain portion of those reaches.

The first method utilized the ratio of the Sed/Soil Cs-137 activity to the Sediment Cs-137 activity in the reaches (compartments) of LTR and SC which received elevated reactor discharges of cooling water. In these compartments most of the residual Cs-137 inventory is tied up in the floodplain sediments directly adjacent to the stream. In SC above and below L-Lake and in LTR below the Par Pond dam, the ratios of Sed/Soil inventory to Sediment inventory (for Cs-137) range from 38.8 to 241. So, using a nominal 100X factor and the PB Sediment inventory, the PB Sed/Soil Cs-137 inventory for the Indian Grave and the Lower PB compartments can be estimated to be $(0.013+0.001) * 100=1.45 \mathrm{Ci}$.

The second method relates the ratio of total Cs-137 inventory of SC to the total estimated releases to the stream and multiplies that by the estimated total release of Cs-137 to PB to compute the total Cs-137 inventory for PB. That calculation computes the Cs-137 residual Sed/Soil activity to be $1.52 \mathrm{Ci}$.

Using the average of these two estimates, a Cs-137 inventory of $1.48 \mathrm{Ci}$ for the Sed/Soil is computed. The ratio of Cs-137 Sediment inventory to Sed/Soil inventory is 1.48/0.0166, or 89.16. This ratio was utilized to multiply the Sediment inventory for all radionuclides in a given PB compartment to determine the associated Sed/Soil inventory for the same radionuclides.

\subsection{Uncertainty Evaluation}

One of the objectives of this investigation is to evaluate the uncertainty associated with the estimated radionuclide inventories for the FMB, PB, and SC IOUs.

One source of uncertainty is associated with the laboratory analyses of Sediment and Sed/Soil samples. Uncertainty arises when instruments of different sensitivity and detection limits are utilized to analyze the multiple samples that are later used to compute a representative central value. 
An algorithm was developed to capture analytical uncertainty due to analytical counting error expressed as a +/- uncertainty in concentration, on an analyte-specific basis. In general, analytes with an aggregate mean concentration less than $1 \mathrm{E}-09 \mathrm{Ci} / \mathrm{kg}$, the analytical uncertainty was taken as $+/$ - the median detection limit. For analytes with aggregate mean concentrations greater than $1 \mathrm{E}-09 \mathrm{Ci} / \mathrm{kg}$, the analytical uncertainty of was taken as $+/-10 \%$ the concentration. This algorithm was implemented in the following fashion.

For each radionuclide then, the weighted mean concentration for each IOU was determined by summing the product of the mean concentration and the number of samples in each IOU compartment, then dividing by the total number of samples from within the IOU. Following this, the aggregated weighted mean concentration was determined by summing the product of the IOU weighted mean concentration and the associated number of samples for each of the IOUs, and then dividing by the total number of samples within all three IOUs. The aggregated mean concentrations were then utilized in conjunction with the algorithm, described above, to determine the uncertainty $+/-\%$. This uncertainty $+/-\%$, along with the relevant median detection limits, the number of samples and the weighted mean concentrations are presented in Table 3-6.

Using this logic, counting error uncertainty appears to be larger as the weighted mean approaches the median instrument detection limits, especially when relatively few analytical results fall close to the detection limit. See the values listed in Table 3-6. With a few of radionuclides, the algorithm to compute the lower-end estimate computes a small negative (-) result. These negative concentrations were truncated at zero.

Related to counting error uncertainty, there is uncertainty that can be introduced due to certain radionuclides lending themselves to misidentification that results in false positives, thus introducing a high bias. This has to do with limitations in the chemical separation or energy discrimination, and would include C-14, Ni-63 and Tc-99 in wet material due to the presence of H-3; I-129 in samples which also contain Cs-137; and Am-241 and Pu-238 in any sample due to interference by natural Th-228. The uncertainty related to this issue was not quantified but an attempt was made to minimize such biases by not utilizing older analytical results which are thought to be prone to this due to certain analytical procedures that were widely used at that time. Another type of analytical uncertainty may be introduced due to biased sampling programs. Also, many Sed/Soil samples were collected and/or analyzed on a biased sampling basis, and speciated for fission products (or TRU) based on elevated Gross alpha or Nonvolatile beta. Therefore, the sample set utilized in this investigation may actually be an overestimate by some unknown amount.

Another source of uncertainty relates to the computation of the mass of contaminated Sediment and Soil/Sediment associated with a particular sub-compartment/sub-section of the IOU being evaluated. An attempt was made to quantify this component of the total uncertainty in the inventory estimate. The approach was to establish a representative length, width and depth of the contaminated Sediment and Sed/Soil associated with each compartment or sub-section. These were used to compute the volume of contaminated material which was then multiplied by a representative bulk density to obtain the mass of contaminated material. There is uncertainty associated with the estimate for each of these geometric factors used in this computation. For Sediment sample the "width" refers to the width of flowing water within the stream. For Sed/Soil samples, it is the width of floodplain sediment on either side of the stream, or the band of dry land immediately on the landward side of a lake perimeter. This width was defined by examining the LIDAR land surface contours which define the land surface configuration in the vicinity of these 
Table 3-6. $\quad$ Estimated Aggregate Analytical Uncertainty by Radionuclide

\begin{tabular}{|l|c|c|c|c|}
\hline Radionuclide & $\begin{array}{c}\text { Median } \\
\text { Detection Limit } \\
\text { (Ci/kg) }\end{array}$ & $\begin{array}{c}\text { No. } \\
\text { samples }\end{array}$ & $\begin{array}{c}\text { Weighted Mean } \\
\text { Concentration } \\
\text { (Ci/kg) }\end{array}$ & $\begin{array}{c}\text { Estimated } \\
\text { Uncertainty } \\
+/-\%\end{array}$ \\
\hline Am-241 & $2.0 \mathrm{E}-10$ & 190 & $7.25 \mathrm{E}-10$ & 27.6 \\
\hline Am-243 & $2.0 \mathrm{E}-10$ & 10 & $3.56 \mathrm{E}-10$ & 56.1 \\
\hline C-14 & $5.0 \mathrm{E}-10$ & 22 & $5.14 \mathrm{E}-10$ & 97.2 \\
\hline Cs-137 & $1.0 \mathrm{E}-10$ & 990 & $1.38 \mathrm{E}-08$ & 10.0 \\
\hline Co-60 & $5.0 \mathrm{E}-11$ & 779 & $6.73 \mathrm{E}-11$ & 74.3 \\
\hline Cm-243/4 & $3.0 \mathrm{E}-10$ & 208 & $7.61 \mathrm{E}-10$ & 39.4 \\
\hline Eu-154 & $6.0 \mathrm{E}-11$ & 2 & $1.80 \mathrm{E}-10$ & 33.3 \\
\hline I-129 & $4.0 \mathrm{E}-10$ & 72 & $4.64 \mathrm{E}-09$ & 10.0 \\
\hline Np-237 & $6.0 \mathrm{E}-11$ & 51 & $2.68 \mathrm{E}-10$ & 22.4 \\
\hline Ni-63 & $2.0 \mathrm{E}-09$ & 25 & $2.01 \mathrm{E}-09$ & 10.0 \\
\hline Pu-238 & $5.0 \mathrm{E}-11$ & 436 & $2.13 \mathrm{E}-10$ & 23.5 \\
\hline Pu-239 & $2.0 \mathrm{E}-11$ & 485 & $9.58 \mathrm{E}-11$ & 20.9 \\
\hline Pu-242 & -- & 3 & $3.46 \mathrm{E}-09$ & 10.0 \\
\hline Sr-90 & $4.0 \mathrm{E}-10$ & 544 & $3.13 \mathrm{E}-09$ & 10.0 \\
\hline Tc-99 & $6.0 \mathrm{E}-10$ & 83 & $6.22 \mathrm{E}-09$ & 10.0 \\
\hline Th-230 & $2.0 \mathrm{E}-10$ & 39 & $1.40 \mathrm{E}-09$ & 10.0 \\
\hline U-234 & $1.0 \mathrm{E}-10$ & 168 & $1.10 \mathrm{E}-08$ & 10.0 \\
\hline U-235 & $6.0 \mathrm{E}-11$ & 168 & $1.10 \mathrm{E}-09$ & 10.0 \\
\hline U-238 & $7.0 \mathrm{E}-11$ & 170 & $1.46 \mathrm{E}-08$ & 10.0 \\
\hline
\end{tabular}

regions. In each case, professional judgment was drawn upon to obtain the degree of certainty thought to be associated with each component of the calculation.

- Contaminated material length $\quad+/-1 \%$

- Contaminated material width $\quad+/-5 \%$

- Contaminated material depth $\quad+/-2 \%$

- Soil bulk density $\quad$ +/- $2 \%$

Similarly, for the Sediments contained beneath L-Lake, these estimates are:
- $\quad$ Area of L-Lake
$+/-1 \%$
- Contaminated material depth
$+/-2 \%$
- Soil Bulk density
$+/-2 \%$

Using these estimates of the range of key parameters used in computing the radionuclide inventory, a range of Cs-137 inventory was computed for the three largest contributing bodies of contaminated sediment within each IOU. For FMB this is the Middle compartment Sed/Soil, for PB IOU it's the Lower Compartment Sediment and for SC IOU it's the Lower compartment Sed/Soil. Summing together the low-range estimates and high-range estimates for the three principal contaminated material bodies the overall range in Cs-137 activity was computed to be approximately $+/-9.6 \%$ for all three IOUs, or a nominal $+/-10 \%$. This nominal $+/-10 \%$ range is assumed to apply equally to all other DOE added radionuclides besides Cs-137. 
Because the computed radionuclide inventories reported in Table 3-4 were calculated by multiplying the estimated mass of contaminated material by the mean concentration, the associated uncertainty associated with those estimates is the sum of the analytical uncertainty associated with each radionuclide plus the nominal $+/-10 \%$ uncertainty associated with the calculation of the mass of contaminated material. The overall uncertainty, by radionuclide, is presented below in Table 3-7.

Table 3-7. Total Uncertainty Associated with Radionuclide Inventory Estimates

\begin{tabular}{|l|c|c|c|}
\hline Radionuclide & $\begin{array}{c}\text { Analytical } \\
\text { Uncertainty } \\
(+/-\%)\end{array}$ & $\begin{array}{c}\text { Contaminated } \\
\text { Mass } \\
\text { Uncertainty } \\
(+/-\%)\end{array}$ & $\begin{array}{c}\text { Total Associated } \\
\text { Uncertainty } \\
(+/-\%)\end{array}$ \\
\hline Am-241 & 28 & 10 & 38 \\
\hline Am-243 & 56 & 10 & 66 \\
\hline C-14 & 97 & 10 & 107 \\
\hline Cs-137 & 10 & 10 & 20 \\
\hline Co-60 & 74 & 10 & 84 \\
\hline Cm-243/4 & 39 & 10 & 49 \\
\hline Eu-154 & 33 & 10 & 43 \\
\hline I-129 & 10 & 10 & 20 \\
\hline Np-237 & 22 & 10 & 32 \\
\hline Ni-63 & 10 & 10 & 20 \\
\hline Pu-238 & 24 & 10 & 34 \\
\hline Pu-239 & 21 & 10 & 31 \\
\hline Pu-242 & 10 & 10 & 20 \\
\hline Sr-90 & 10 & 10 & 20 \\
\hline Tc-99 & 10 & 10 & 20 \\
\hline Th-230 & 10 & 10 & 20 \\
\hline U-234 & 10 & 10 & 20 \\
\hline U-235 & 10 & 10 & 20 \\
\hline U-238 & 10 & 10 & \\
\hline
\end{tabular}

The upper and lower bounding radionuclide inventory estimates are calculated by applying the total uncertainty shown in Table 3-7 to the rolled-up radionuclide inventory values presented in Table 3-4. The result of this is presented in Table 3-8. 
Table 3-8 Upper and Lower Bounding Radionuclide Inventory Estimates

\begin{tabular}{|c|c|c|c|c|c|c|}
\hline Nuclide & $\begin{array}{c}\text { FMB IOU } \\
\text { Upper } \\
\text { Estimate } \\
\mathbf{( C i )}\end{array}$ & $\begin{array}{c}\text { FMB IOU } \\
\text { Lower } \\
\text { Estimate } \\
\mathbf{( C i )}\end{array}$ & $\begin{array}{c}\text { PB IOU } \\
\text { Upper } \\
\text { Estimate } \\
\mathbf{( C i )}\end{array}$ & $\begin{array}{c}\text { PB IOU } \\
\text { Lower } \\
\text { Estimate } \\
\mathbf{( C i )}\end{array}$ & $\begin{array}{c}\text { SC IOU } \\
\text { Upper } \\
\text { Estimate } \\
\text { (Ci) }\end{array}$ & $\begin{array}{c}\text { SC IOU } \\
\text { Lower } \\
\text { Estimate } \\
\text { (Ci) }\end{array}$ \\
\hline Am-241 & $6.27 \mathrm{E}-01$ & $2.81 \mathrm{E}-01$ & -- & -- & $3.38 \mathrm{E}-04$ & $1.52 \mathrm{E}-04$ \\
\hline Am-243 & $3.15 \mathrm{E}-01$ & $6.46 \mathrm{E}-02$ & -- & -- & -- & -- \\
\hline C-14 & $1.67 \mathrm{E}-03$ & $0.00 \mathrm{E}+00$ & -- & -- & $5.80 \mathrm{E}-03$ & $0.00 \mathrm{E}+00$ \\
\hline Cs-137 & $1.10 \mathrm{E}+01$ & $7.30 \mathrm{E}+00$ & $1.80 \mathrm{E}+00$ & $1.20 \mathrm{E}+00$ & $2.09 \mathrm{E}+01$ & $1.39 \mathrm{E}+01$ \\
\hline Co-60 & $1.72 \mathrm{E}-01$ & $1.50 \mathrm{E}-02$ & $1.12 \mathrm{E}-01$ & $9.74 \mathrm{E}-03$ & $1.30 \mathrm{E}-01$ & $1.13 \mathrm{E}-02$ \\
\hline Cm-244 & $6.87 \mathrm{E}-01$ & $2.41 \mathrm{E}-01$ & $2.50 \mathrm{E}-03$ & $8.79 \mathrm{E}-04$ & $1.27 \mathrm{E}-02$ & $4.47 \mathrm{E}-03$ \\
\hline Eu-154 & $2.37 \mathrm{E}-02$ & $9.46 \mathrm{E}-03$ & -- & -- & -- & -- \\
\hline I-129 & $5.41 \mathrm{E}+00$ & $3.61 \mathrm{E}+00$ & $1.48 \mathrm{E}-01$ & $9.84 \mathrm{E}-02$ & -- & -- \\
\hline Np-237 & $8.25 \mathrm{E}-02$ & $4.25 \mathrm{E}-02$ & -- & -- & $3.33 \mathrm{E}-01$ & $1.71 \mathrm{E}-01$ \\
\hline Ni-63 & $2.69 \mathrm{E}-01$ & $1.79 \mathrm{E}-01$ & -- & -- & $2.24 \mathrm{E}-01$ & $1.49 \mathrm{E}-01$ \\
\hline Pu-238 & $2.64 \mathrm{E}-01$ & $1.30 \mathrm{E}-01$ & $5.16 \mathrm{E}-03$ & $2.54 \mathrm{E}-03$ & $8.08 \mathrm{E}-02$ & $3.98 \mathrm{E}-02$ \\
\hline Pu-239 & $9.60 \mathrm{E}-02$ & $4.84 \mathrm{E}-02$ & $2.21 \mathrm{E}-02$ & $1.11 \mathrm{E}-02$ & $7.08 \mathrm{E}-02$ & $3.57 \mathrm{E}-02$ \\
\hline Pu-242 & -- & -- & $2.41 \mathrm{E}+00$ & $1.61 \mathrm{E}+00$ & -- & - \\
\hline Sr-90 & $3.80 \mathrm{E}+00$ & $2.54 \mathrm{E}+00$ & $2.27 \mathrm{E}-02$ & $1.51 \mathrm{E}-02$ & $4.52 \mathrm{E}-01$ & $3.01 \mathrm{E}-01$ \\
\hline Tc-99 & $4.15 \mathrm{E}+00$ & $2.77 \mathrm{E}+00$ & $1.17 \mathrm{E}-01$ & $7.79 \mathrm{E}-02$ & $7.91 \mathrm{E}-03$ & $5.27 \mathrm{E}-03$ \\
\hline Th-230 & $4.62 \mathrm{E}-02$ & $3.08 \mathrm{E}-02$ & -- & -- & $2.12 \mathrm{E}-01$ & $1.42 \mathrm{E}-01$ \\
\hline U-234 & $4.98 \mathrm{E}+00$ & $3.32 \mathrm{E}+00$ & -- & -- & $4.84 \mathrm{E}-02$ & $3.22 \mathrm{E}-02$ \\
\hline U-235 & $4.49 \mathrm{E}-01$ & $2.99 \mathrm{E}-01$ & -- & -- & $3.62 \mathrm{E}-03$ & $2.41 \mathrm{E}-03$ \\
\hline U-238 & $6.55 \mathrm{E}+00$ & $4.37 \mathrm{E}+00$ & -- & -- & $4.80 \mathrm{E}-02$ & $3.20 \mathrm{E}-02$ \\
\hline
\end{tabular}

Comparing the upper bounding estimate for Cs-137 for each of the IOUs from this uncertainty approach to the 1985 estimate (Gladden, et. al.) of Cs-137 activity decayed to 2013, the upper bounding estimate for SC (20.9 Ci) is very close to the independent estimate based on the 1982 EIS soil core $(21.1 \mathrm{Ci})$. This is the most significant IOU in terms of Cs-137 releases from SRS operations. The current upper bounding Cs-137 estimate for FMB is $10.0 \mathrm{Ci}$ versus $21 \mathrm{Ci}$; and the upper bounding estimate for $\mathrm{PB}$ is $1.65 \mathrm{Ci}$ versus $5.99 \mathrm{Ci}$. 
SRNL-STI-2013-00592

Revision 0

\subsection{References}

Carilli, J. T. and Golian, S. 2010. Savannah River Site Composite Analysis Review Report, Department of Energy Low-Level Waste Disposal Facility Federal Review Group Review Team, April 20, 2010.

Carlton, W. H., Bauer, L. R., Evans, A. G., Geary, L. A., Murphy, C. E., Pinder, J. E., and Strom, R. N. 1992. Cesium in the Savannah River Site Environment (U), WSRC-RP-92-250, Westinghouse Savannah River Company, Aiken, SC. March 1992.

DOE/EH-0173T. 1991. Environmental Regulatory Guide for Radiological Effluent Monitoring and Environmental Surveillance, 1991.

DuPont, 1982. Savannah River Plant Area Drainage Systems. DPST-81-1045, Rev. 8/82. E.I. DuPont de Nemours Co, Inc. Savannah River Plant.

DuPont, 1982a. Release of Radioactivity at the Savannah River Plant. DPSPU-82-25-1, E.I DuPont de Nemours Co, Inc. Savannah River Plant.

ERD (Environmental Restoration Department). 2001. Environmental Restoration Division Response to the Site wide EM Risk/Hazard Analysis, Environmental Restoration Division Internal Memorandum from W. A. Wilson to T. F. Gaughan, ERD-2001-00950, Westinghouse Savannah River Company, Aiken, SC.

Gladden, J.B. et. al. 1985. Comprehensive Cooling Water Study Annual Report. DP-1697-4. E.I. du Pont de Nemours Co. Inc. July 1985.

Hiergesell, R. A., M. A. Phifer, J. R. Cook, K. E. Young, M. B. Birk, W. B. Dean. 2008. Inventory of Residual Radioactive Material at the Projected Savannah River Site End State. SRNL-STI-2008-00380, Rev. 0. Savannah River Nuclear Solutions. Aiken, SC 29808.

Hiergesell, R.A., M.A. Phifer. 2012. Radionuclide Inventory and Distribution: Lower Three Runs IOU. SRNL-STI-2012-00524, Revision 0. Savannah River Nuclear Solutions. Aiken, SC 29808.

Jannik, G. T. SRNL-Environmental Restoration Technology Section. Verbal communication.

Kubilius, W.P. SRNS-ACP Engineering \& Technology, email to R. A. Hiergesell and M. A. Phifer, August 12, 2013.

Marcinowski 2010. Memorandum from Frank Marcinowski to Terrel Spears, July 16, 2010. Approval of the Savannah River Site Department of Energy 435.1 Composite Analysis, Rev. 0.

Phifer, M. A., Millings, M. R., and Flach, G. P. 2006. Hydraulic Property Data Package for the EArea and Z-Area Soils, Cementitious Materials, and Waste Zones, WSRC-STI-2006-00198, Rev. 0, Savannah River National Laboratory, Washington Savannah River Company, Aiken, SC, September 2006.

SRNL 2010. Savannah River DOE 435.1 Composite Analysis, SRNL-STI-2009-00512, Revision 0, Volumes I and II, Savannah River National Laboratory, Aiken, SC. June 10, 2010. 
SRNL-STI-2013-00592

Revision 0

SRNS 2010a. Periodic Report 3 for the Pen Branch Integrator Operable Unit (U), SRNS-RP2010-00587, Rev. 1, Savannah River Nuclear Solutions. Aiken, SC. November, 2010.

SRNS 2010b. Periodic Report 4 for the Steel Creek Integrator Operable Unit (U), SRNS-RP2009-00785, Rev. 1, Savannah River Nuclear Solutions. Aiken, SC. January, 2010.

SRNS 2012. Periodic Report 4 for the Fourmile Branch Integrator Operable Unit (U), SRNS-RP2011-01359, Rev. 1, Savannah River Nuclear Solutions. Aiken, SC. May, 2012.

WSRC 2002a. Remedial Investigation Work Plan for the Pen Branch Integrator Operable Unit (U). WSRC-RP-2001-4262, Rev. 1. Westinghouse Savannah River Company. Aiken, SC. October, 2002.

WSRC 2002b. Periodic Report for the Steel Creek Integrator Operable Unit (U), WSRC-RP2002-4009, Rev. 1, Westinghouse Savannah River Company. Aiken, SC. November, 2002.

WSRC 2003. Periodic Report for the Fourmile Branch Integrator Operable Unit (U). WSRC-RP2002-4139, Rev. 1.0, Westinghouse Savannah River Company. Aiken, SC. August, 2003.

WSRC 2004a. Periodic Report 2 for the Pen Branch Integrator Operable Unit (U), WSRC-RP2003-4152, Rev. 1, Westinghouse Savannah River Company. Aiken, SC. September, 2004.

WSRC 2004b. Periodic Report 2 for the Steel Creek Integrator Operable Unit (U), WSRC-RP2003-4153, Rev. 2, Westinghouse Savannah River Company. Aiken, SC. August, 2004.

WSRC 2005. Periodic Report 2 for the Fourmile Branch Integrator Operable Unit (U), WSRCRP-2004-4109, Rev. 1, Westinghouse Savannah River Company. Aiken, SC. October, 2005.

WSRC 2007a. Periodic Report 3 for the Steel Creek Integrator Operable Unit (U), WSRC-RP2006-4017, Rev. 1, Washington Savannah River Company. Aiken, SC. April, 2007.

WSRC 2007b. Periodic Report 2 for the Pen Branch Integrator Operable Unit (U), WSRC-RP2007-4019, Rev. 1, Washington Savannah River Company. Aiken, SC. September, 2007.

WSRC 2008. Periodic Report 3 for the Fourmile Branch Integrator Operable Unit (U), WSRCRP-2007-4071, Rev. 1, Washington Savannah River Company. Aiken, SC. October, 2008. 
SRNL-STI-2013-00592

Revision 0

\section{APPENDIX A}

Sediment and Soil/Sediment Analytical Data for each FMB, PB, and SC IOU SubCompartments 
Table A-0-1 FMB Compartments - Samples, Mean Concentrations and Inventories

FMB-Lower Compartment

\begin{tabular}{|l|c|c|c|c|c|c|}
\hline Radionuclide & $\begin{array}{c}\text { No. } \\
\text { Sediment } \\
\text { Samples }\end{array}$ & $\begin{array}{c}\text { Sediment } \\
\text { Mean } \\
\text { Conc.Ci/kg }\end{array}$ & $\begin{array}{c}\text { Sediment } \\
\text { Inventory(Ci) }\end{array}$ & $\begin{array}{c}\text { No. } \\
\text { Sed/Soil } \\
\text { Samples }\end{array}$ & $\begin{array}{c}\text { Sed/Soil } \\
\text { Mean } \\
\text { Conc. } \\
\text { Ci/kg }\end{array}$ & $\begin{array}{c}\text { Sed/Soil } \\
\text { Inventory } \\
\text { (Ci) }\end{array}$ \\
\hline & & & & & & \\
\hline Am-241 & $12(4)$ & $9.25 \mathrm{E}-11$ & $1.94 \mathrm{E}-03$ & --- & --- & --- \\
\hline Am-243 & --- & --- & --- & -- & --- & --- \\
\hline C-14 & --- & --- & --- & --- & -- & -- \\
\hline Cs-137 & $59(8)$ & $4.91 \mathrm{E}-09$ & $1.03 \mathrm{E}-01$ & $65(17)$ & $3.94 \mathrm{E}-09$ & $1.71 \mathrm{E}+00$ \\
\hline Co-60 & $45(18)$ & $8.63 \mathrm{E}-11$ & $1.81 \mathrm{E}-03$ & $53(18)$ & $4.36 \mathrm{E}-11$ & $1.89 \mathrm{E}-02$ \\
\hline Cm-244 & $10(2)$ & $2.09 \mathrm{E}-11$ & $4.38 \mathrm{E}-04$ & $10(2)$ & $2.09 \mathrm{E}-11$ & $9.09 \mathrm{E}-03$ \\
\hline Eu-154 & --- & --- & --- & --- & --- & --- \\
\hline I-129 & $3(1)$ & $1.03 \mathrm{E}-10$ & $2.16 \mathrm{E}-03$ & --- & --- & --- \\
\hline Np-237 & $2(1)$ & $5.00 \mathrm{E}-12$ & $1.05 \mathrm{E}-04$ & --- & --- & --- \\
\hline Ni-63 & --- & --- & --- & --- & --- & -- \\
\hline Pu-238 & $13(3)$ & $1.91 \mathrm{E}-11$ & $4.00 \mathrm{E}-04$ & $43(8)$ & $9.61 \mathrm{E}-12$ & $4.17 \mathrm{E}-03$ \\
\hline Pu-239 & $15(7)$ & $1.53 \mathrm{E}-11$ & $3.21 \mathrm{E}-04$ & $43(7)$ & $1.72 \mathrm{E}-11$ & $7.47 \mathrm{E}-03$ \\
\hline Sr-90 & $13(5)$ & $4.73 \mathrm{E}-10$ & $9.90 \mathrm{E}-03$ & $53(38)$ & $6.52 \mathrm{E}-11$ & $2.83 \mathrm{E}-02$ \\
\hline Tc-99 & $4(1)$ & $1.85 \mathrm{E}-10$ & $3.87 \mathrm{E}-03$ & --- & --- & --- \\
\hline
\end{tabular}

${ }^{1}$ Parentheses indicates \#<detection 
FMB Middle Compartment

\begin{tabular}{|l|c|c|c|c|c|c|}
\hline Radionuclide & $\begin{array}{c}\text { No. } \\
\text { Sediment } \\
\text { Samples }\end{array}$ & $\begin{array}{c}\text { Sediment } \\
\text { Mean } \\
\text { Conc.Ci/kg }\end{array}$ & $\begin{array}{c}\text { Sediment } \\
\text { Inventory } \\
\mathbf{( C i )}\end{array}$ & $\begin{array}{c}\text { No. } \\
\text { Sed/Soil } \\
\text { Samples }\end{array}$ & $\begin{array}{c}\text { Sed/Soil } \\
\text { Mean } \\
\text { Conc. } \\
\text { Ci/kg }\end{array}$ & $\begin{array}{c}\text { Sed/Soil } \\
\text { Inventory } \\
\text { (Ci) }\end{array}$ \\
\hline Am-241 & $42(5)$ & $4.70 \mathrm{E}-10$ & $5.97 \mathrm{E}-03$ & $3(0)$ & $1.42 \mathrm{E}-09$ & $3.28 \mathrm{E}-01$ \\
\hline Am-243 & $3(0)$ & $1.58 \mathrm{E}-10$ & $2.00 \mathrm{E}-03$ & $2(0)$ & $6.75 \mathrm{E}-10$ & $1.56 \mathrm{E}-01$ \\
\hline Cs-137 & $80(2)$ & $2.65 \mathrm{E}-08$ & $3.36 \mathrm{E}-01$ & $46(4)$ & $2.63 \mathrm{E}-08$ & $6.06 \mathrm{E}+00$ \\
\hline Co-60 & $68(33)$ & $3.31 \mathrm{E}-11$ & $4.21 \mathrm{E}-04$ & $36(22)$ & $2.18 \mathrm{E}-11$ & $5.04 \mathrm{E}-03$ \\
\hline Cm-244 & $40(6)$ & $2.92 \mathrm{E}-10$ & $3.71 \mathrm{E}-03$ & $3(0)$ & $1.45 \mathrm{E}-09$ & $3.34 \mathrm{E}-01$ \\
\hline I-129 & $7(4)$ & $7.26 \mathrm{E}-10$ & $9.22 \mathrm{E}-03$ & --- & --- & --- \\
\hline Np-237 & $14(7)$ & $3.14 \mathrm{E}-11$ & $3.99 \mathrm{E}-04$ & $2(1)$ & $4.00 \mathrm{E}-11$ & $9.24 \mathrm{E}-03$ \\
\hline Ni-63 & $5(3)$ & $1.41 \mathrm{E}-09$ & $1.79 \mathrm{E}-02$ & --- & --- & --- \\
\hline Pu-238 & $65(3)$ & $8.44 \mathrm{E}-10$ & $1.07 \mathrm{E}-02$ & $39(0)$ & $5.85 \mathrm{E}-10$ & $1.35 \mathrm{E}-01$ \\
\hline Pu-239 & $68(8)$ & $1.82 \mathrm{E}-10$ & $2.31 \mathrm{E}-03$ & $39(3)$ & $2.03 \mathrm{E}-10$ & $4.69 \mathrm{E}-02$ \\
\hline Sr-90 & $63(12)$ & $6.96 \mathrm{E}-10$ & $8.84 \mathrm{E}-03$ & $38(16)$ & $2.31 \mathrm{E}-10$ & $5.34 \mathrm{E}-02$ \\
\hline Tc-99 & $12(4)$ & $3.99 \mathrm{E}-09$ & $5.07 \mathrm{E}-02$ & $1(0)$ & $1.04 \mathrm{E}-09$ & $2.40 \mathrm{E}-01$ \\
\hline Th-230 & $8(0)$ & $1.37 \mathrm{E}-09$ & -- & $3(0)$ & $1.57 \mathrm{E}-09$ & $3.85 \mathrm{E}-02$ \\
\hline U-234 & $35(0)$ & $8.34 \mathrm{E}-10$ & $1.06 \mathrm{E}-02$ & $3(0)$ & $9.63 \mathrm{E}-09$ & $2.22 \mathrm{E}+00$ \\
\hline U-235 & $35(2)$ & $1.76 \mathrm{E}-10$ & $2.24 \mathrm{E}-03$ & $3(0)$ & $7.75 \mathrm{E}-10$ & $1.79 \mathrm{E}-01$ \\
\hline U-238 & $37(0)$ & $1.73 \mathrm{E}-09$ & $2.19 \mathrm{E}-02$ & $3(0)$ & $1.23 \mathrm{E}-08$ & $2.83 \mathrm{E}+00$ \\
\hline
\end{tabular}

${ }^{1}$ Parentheses indicates \#<detection

F-Seepage Area

\begin{tabular}{|l|c|c|c|c|c|c|}
\hline Radionuclide & $\begin{array}{c}\text { No. } \\
\text { Sediment } \\
\text { Samples }\end{array}$ & $\begin{array}{c}\text { Sediment } \\
\text { Mean } \\
\text { Conc. } \\
\text { Ci/kg }\end{array}$ & $\begin{array}{c}\text { Sediment } \\
\text { Inventory } \\
\text { (Ci) }\end{array}$ & $\begin{array}{c}\text { No. } \\
\text { Sed/Soil } \\
\text { Samples }\end{array}$ & $\begin{array}{c}\text { Sed/Soil } \\
\text { Mean } \\
\text { Conc. } \\
\text { Ci/kg }\end{array}$ & $\begin{array}{c}\text { Sed/Soil } \\
\text { Inventory } \\
\text { (Ci) }\end{array}$ \\
\hline Am-241 & & --- & --- & 83 & $1.27 \mathrm{E}-09$ & $6.45 \mathrm{E}-03$ \\
\hline Am-243 & --- & --- & $5(3)$ & $3.48 \mathrm{E}-10$ & $3.22 \mathrm{E}-02$ \\
\hline Cs-137 & --- & --- & --- & $72(11)$ & $9.58 \mathrm{E}-09$ & $8.85 \mathrm{E}-01$ \\
\hline Co-60 & --- & --- & --- & $73(63)$ & $2.10 \mathrm{E}-11$ & $1.94 \mathrm{E}-03$ \\
\hline Cm-244 & --- & --- & --- & 83 & $1.24 \mathrm{E}-09$ & $6.05 \mathrm{E}-03$ \\
\hline Eu-154 & --- & --- & --- & $2(1)$ & $1.80 \mathrm{E}-10$ & $1.66 \mathrm{E}-02$ \\
\hline I-129 & --- & --- & --- & $6(1)$ & $4.69 \mathrm{E}-08$ & $4.33 \mathrm{E}+00$ \\
\hline Np-237 & --- & --- & --- & $6(3)$ & $3.50 \mathrm{E}-11$ & $3.23 \mathrm{E}-03$ \\
\hline Ni-63 & --- & --- & --- & $1(0)$ & $2.23 \mathrm{E}-09$ & $2.06 \mathrm{E}-01$ \\
\hline Pu-238 & --- & --- & --- & $6(5)$ & $5.01 \mathrm{E}-10$ & $4.63 \mathrm{E}-02$ \\
\hline Pu-239 & --- & --- & --- & $6(5)$ & $1.62 \mathrm{E}-10$ & $1.49 \mathrm{E}-02$ \\
\hline Sr-90 & --- & --- & --- & $74(32)$ & $6.31 \mathrm{E}-09$ & $5.83 \mathrm{E}-01$ \\
\hline Tc-99 & --- & --- & --- & $6(1)$ & $2.15 \mathrm{E}-08$ & $1.98 \mathrm{E}+00$ \\
\hline Th-230 & --- & --- & --- & $6(2)$ & $6.20 \mathrm{E}-10$ & $5.73 \mathrm{E}-02$ \\
\hline U-234 & --- & --- & --- & 83 & $2.07 \mathrm{E}-08$ & $8.05 \mathrm{E}-02$ \\
\hline U-235 & --- & --- & ---09 & $9.61 \mathrm{E}-03$ \\
\hline U-238 & --- & -- & -- & 83 & $2.82 \mathrm{E}-08$ & $1.09 \mathrm{E}-01$ \\
\hline
\end{tabular}

\footnotetext{
${ }^{1}$ Parentheses indicates \#<detection
} 
F-Area Tributary to FMB

\begin{tabular}{|l|c|c|c|c|c|c|}
\hline Radionuclide & $\begin{array}{c}\text { No. } \\
\text { Sediment } \\
\text { Samples }\end{array}$ & $\begin{array}{c}\text { Sediment } \\
\text { Mean } \\
\text { Conc. } \\
\text { Ci/kg }\end{array}$ & $\begin{array}{c}\text { Sediment } \\
\text { Inventory } \\
\text { (Ci) }\end{array}$ & $\begin{array}{c}\text { No. } \\
\text { Sed/Soil } \\
\text { Samples }\end{array}$ & $\begin{array}{c}\text { Sed/Soil } \\
\text { Mean } \\
\text { Conc. } \\
\text { Ci/kg }\end{array}$ & $\begin{array}{c}\text { Sed/Soil } \\
\text { Inventory } \\
\text { (Ci) }\end{array}$ \\
\hline & & & & & & \\
\hline Am-241 & $19(10)$ & $3.15 \mathrm{E}-10$ & $1.65 \mathrm{E}-04$ & $9(5)$ & $7.22 \mathrm{E}-11$ & $1.33 \mathrm{E}-04$ \\
\hline C-14 & $11(6)$ & $2.19 \mathrm{E}-10$ & $1.14 \mathrm{E}-04$ & $5(3)$ & $3.77 \mathrm{E}-10$ & $6.92 \mathrm{E}-04$ \\
\hline Cs-137 & $26(0)$ & $4.30 \mathrm{E}-09$ & $2.25 \mathrm{E}-03$ & $18(0)$ & $7.79 \mathrm{E}-10$ & $1.43 \mathrm{E}-03$ \\
\hline Co-60 & $26(14)$ & $3.81 \mathrm{E}-12$ & $1.99 \mathrm{E}-06$ & $17(16)$ & $2.55 \mathrm{E}-13$ & $4.68 \mathrm{E}-07$ \\
\hline Cm-244 & $9(2)$ & $4.95 \mathrm{E}-12$ & $2.59 \mathrm{E}-06$ & $9(3)$ & $3.30 \mathrm{E}-10$ & $6.06 \mathrm{E}-04$ \\
\hline I-129 & $11(10)$ & $2.75 \mathrm{E}-10$ & $1.44 \mathrm{E}-04$ & $5(3)$ & $2.14 \mathrm{E}-10$ & $3.93 \mathrm{E}-04$ \\
\hline Ni-63 & $10(0)$ & $8.99 \mathrm{E}-10$ & $4.70 \mathrm{E}-04$ & --- & --- & \\
\hline Pu-238 & $24(6)$ & $1.59 \mathrm{E}-10$ & $8.30 \mathrm{E}-05$ & $9(6)$ & $4.64 \mathrm{E}-11$ & $8.51 \mathrm{E}-05$ \\
\hline Pu-239 & $25(2)$ & $5.98 \mathrm{E}-10$ & $3.13 \mathrm{E}-04$ & $9(0)$ & $2.81 \mathrm{E}-10$ & $5.16 \mathrm{E}-04$ \\
\hline Sr-90 & $24(12)$ & $7.41 \mathrm{E}-10$ & $3.87 \mathrm{E}-04$ & $5(3)$ & $8.30 \mathrm{E}-11$ & $1.52 \mathrm{E}-04$ \\
\hline Tc-99 & $11(4)$ & $5.64 \mathrm{E}-10$ & $2.95 \mathrm{E}-04$ & --- & --- & --- \\
\hline U-234 & $19(0)$ & $2.65 \mathrm{E}-09$ & $5.74 \mathrm{E}-04$ & --- & --- & --- \\
\hline U-235 & $19(4)$ & $1.48 \mathrm{E}-10$ & $7.73 \mathrm{E}-05$ & --- & --- & -- \\
\hline U-238 & $19(0)$ & $1.42 \mathrm{E}-09$ & $7.44 \mathrm{E}-04$ & --- & -- & -- \\
\hline
\end{tabular}

${ }^{1}$ Parentheses indicates \#<detection

H-Seepage Area

\begin{tabular}{|l|c|c|c|c|c|c|}
\hline Radionuclide & $\begin{array}{c}\text { No. } \\
\text { Sediment } \\
\text { Samples }\end{array}$ & $\begin{array}{c}\text { Sediment } \\
\text { Mean } \\
\text { Conc. } \\
\text { Ci/kg }\end{array}$ & $\begin{array}{c}\text { Sediment } \\
\text { Inventory } \\
\mathbf{( C i )}\end{array}$ & $\begin{array}{c}\text { No. } \\
\text { Sed/Soil } \\
\text { Samples }\end{array}$ & $\begin{array}{c}\text { Sed/Soil } \\
\text { Mean } \\
\text { Conc. } \\
\text { Ci/kg }\end{array}$ & $\begin{array}{c}\text { Sed/Soil } \\
\text { Inventory } \\
\text { (Ci) }\end{array}$ \\
\hline & & & & & & \\
\hline Cs-137 & --- & --- & --- & $44(3)$ & $2.47 \mathrm{E}-10$ & $2.52 \mathrm{E}-02$ \\
\hline Co-60 & --- & --- & --- & $46(33)$ & $6.41 \mathrm{E}-10$ & $6.54 \mathrm{E}-02$ \\
\hline I-129 & --- & --- & --- & $25(15)$ & $1.66 \mathrm{E}-09$ & $1.69 \mathrm{E}-01$ \\
\hline Np-237 & --- & --- & --- & $26(13)$ & $4.85 \mathrm{E}-10$ & $4.95 \mathrm{E}-02$ \\
\hline Sr-90 & --- & --- & --- & $46(29)$ & $2.43 \mathrm{E}-08$ & $2.48 \mathrm{E}+00$ \\
\hline Tc-99 & --- & --- & --- & $27(11)$ & $1.16 \mathrm{E}-08$ & $1.18 \mathrm{E}+00$ \\
\hline
\end{tabular}

${ }^{1}$ Parentheses indicates \#< detection

H-Area Tributary to FMB

\begin{tabular}{|l|c|c|c|c|c|c|}
\hline Radionuclide & $\begin{array}{c}\text { No. } \\
\text { Sediment } \\
\text { Samples }\end{array}$ & $\begin{array}{c}\text { Sediment } \\
\text { Mean } \\
\text { Conc. } \\
\text { Ci/kg }\end{array}$ & $\begin{array}{c}\text { Sediment } \\
\text { Inventory } \\
\text { (Ci) }\end{array}$ & $\begin{array}{c}\text { No. } \\
\text { Sed/Soil } \\
\text { Samples }\end{array}$ & $\begin{array}{c}\text { Sed/Soil } \\
\text { Mean } \\
\text { Conc. } \\
\text { Ci/kg }\end{array}$ & $\begin{array}{c}\text { Sed/Soil } \\
\text { Inventory } \\
\text { (Ci) }\end{array}$ \\
\hline & & & & & & \\
\hline Cs-137 & $4(0)$ & $7.61 \mathrm{E}-09$ & $2.71 \mathrm{E}-03$ & --- & --- & --- \\
\hline Sr-90 & $3(2)$ & $3.53 \mathrm{E}-10$ & $1.26 \mathrm{E}-04$ & --- & --- & -- \\
\hline
\end{tabular}

${ }^{1}$ Parentheses indicates \#< detection 
FMB Upper

\begin{tabular}{|l|c|c|c|c|c|c|}
\hline Radionuclide & $\begin{array}{c}\text { No. } \\
\text { Sediment } \\
\text { Samples }^{\mathbf{1}}\end{array}$ & $\begin{array}{c}\text { Sediment } \\
\text { Mean } \\
\text { Conc. } \\
\text { Ci/kg }\end{array}$ & $\begin{array}{c}\text { Sediment } \\
\text { Inventory } \\
\text { (Ci) }\end{array}$ & $\begin{array}{c}\text { No. } \\
\text { Sed/Soil } \\
\text { Samples }\end{array}$ & $\begin{array}{c}\text { Sed/Soil } \\
\text { Mean } \\
\text { Conc. } \\
\text { Ci/kg }\end{array}$ & $\begin{array}{c}\text { Sed/Soil } \\
\text { Inventory } \\
\text { (Ci) }\end{array}$ \\
\hline & & & & & & \\
\hline Cs-137 & $3(1)$ & $6.70 \mathrm{E}-11$ & $2.44 \mathrm{E}-04$ & $2(0)$ & $1.36 \mathrm{E}-10$ & $8.66 \mathrm{E}-04$ \\
\hline $\mathrm{Pu}-238$ & --- & --- & --- & $11(5)$ & $2.33 \mathrm{E}-12$ & $1.49 \mathrm{E}-05$ \\
\hline $\mathrm{Pu}-239$ & --- & --- & --- & $11(6)$ & $1.09 \mathrm{E}-11$ & $6.95 \mathrm{E}-05$ \\
\hline $\mathrm{Sr}-90$ & $1(0)$ & $1.48 \mathrm{E}-09$ & $5.40 \mathrm{E}-03$ & $9(8)$ & $1.44 \mathrm{E}-10$ & $9.19 \mathrm{E}-04$ \\
\hline
\end{tabular}

${ }^{1}$ Parentheses indicates \#< detection

FMB Castor Ck.

\begin{tabular}{|l|c|c|c|c|c|c|}
\hline Radionuclide & $\begin{array}{c}\text { No. } \\
\text { Sediment } \\
\text { Samples }^{1}\end{array}$ & $\begin{array}{c}\text { Sediment } \\
\text { Mean } \\
\text { Conc. } \\
\text { Ci/kg }\end{array}$ & $\begin{array}{c}\text { Sediment } \\
\text { Inventory } \\
(\mathbf{C i})\end{array}$ & $\begin{array}{c}\text { No. } \\
\text { Sed/Soil } \\
\text { Samples }\end{array}$ & $\begin{array}{c}\text { Sed/Soil } \\
\text { Mean } \\
\text { Conc. } \\
\text { Ci/kg }\end{array}$ & $\begin{array}{c}\text { Sed/Soil } \\
\text { Inventory } \\
\text { (Ci) }\end{array}$ \\
\hline & & & & & & \\
\hline Cs-137 & $1(0)$ & $9.89 \mathrm{E}-11$ & $2.06 \mathrm{E}-04$ & --- & --- & -- \\
\hline
\end{tabular}

\footnotetext{
${ }^{1}$ Parentheses indicates \#<detection
} 
Table A-0-2 PB Compartments - Samples, Mean Concentrations and Inventories

Pen Br. Lower

\begin{tabular}{|l|c|c|c|c|c|c|}
\hline Radionuclide & $\begin{array}{c}\text { No. } \\
\text { Sediment } \\
\text { Samples }\end{array}$ & $\begin{array}{c}\text { Sediment } \\
\text { Mean } \\
\text { Conc. } \\
\text { Ci/kg }\end{array}$ & $\begin{array}{c}\text { Sediment } \\
\text { Inventory } \\
\text { (Ci) }\end{array}$ & $\begin{array}{c}\text { No. } \\
\text { Sed/Soil } \\
\text { Samples }\end{array}$ & $\begin{array}{c}\text { Sed/Soil } \\
\text { Mean } \\
\text { Conc. } \\
\text { Ci/kg }\end{array}$ & $\begin{array}{c}\text { Sed/Soil } \\
\text { Inventory } \\
\text { (Ci) }\end{array}$ \\
\hline & & & & & & \\
\hline Cs-137 & $98(50)$ & $1.11 \mathrm{E}-09$ & $1.34 \mathrm{E}-02$ & --- & --- & $1.20 \mathrm{E}+00$ \\
\hline Co-60 & $91(63)$ & $4.98 \mathrm{E}-11$ & $6.02 \mathrm{E}-04$ & --- & --- & $5.37 \mathrm{E}-02$ \\
\hline $\mathrm{Cm}-244$ & $15(13)$ & $4.29 \mathrm{E}-13$ & $5.18 \mathrm{E}-06$ & --- & --- & $4.62 \mathrm{E}-04$ \\
\hline $\mathrm{I}-129$ & $15(14)$ & $1.13 \mathrm{E}-10$ & $1.37 \mathrm{E}-03$ & --- & --- & $1.22 \mathrm{E}-01$ \\
\hline Pu-238 & $28(21)$ & $2.15 \mathrm{E}-12$ & $2.60 \mathrm{E}-05$ & --- & --- & $2.31 \mathrm{E}-03$ \\
\hline Pu-239 & $29(16)$ & $7.24 \mathrm{E}-12$ & $8.75 \mathrm{E}-05$ & --- & --- & $7.80 \mathrm{E}-03$ \\
\hline Sr-90 & $27(25)$ & $1.74 \mathrm{E}-11$ & $2.10 \mathrm{E}-04$ & --- & --- & $1.87 \mathrm{E}-02$ \\
\hline Tc-99 & $16(15)$ & $8.94 \mathrm{E}-11$ & $1.08 \mathrm{E}-03$ & --- & --- & $9.63 \mathrm{E}-02$ \\
\hline
\end{tabular}

${ }^{1}$ Parentheses indicates \#< detection

Pen Br. Middle

\begin{tabular}{|l|c|c|c|c|c|c|}
\hline Radionuclide & $\begin{array}{c}\text { No. } \\
\text { Sediment } \\
\text { Samples }\end{array}$ & $\begin{array}{c}\text { Sediment } \\
\text { Mean } \\
\text { Conc. } \\
\text { Ci/kg }\end{array}$ & $\begin{array}{c}\text { Sediment } \\
\text { Inventory } \\
\text { (Ci) }\end{array}$ & $\begin{array}{c}\text { No. } \\
\text { Sed/Soil } \\
\text { Samples }\end{array}$ & $\begin{array}{c}\text { Sed/Soil } \\
\text { Mean } \\
\text { Conc. } \\
\text { Ci/kg }\end{array}$ & $\begin{array}{c}\text { Sed/Soil } \\
\text { Inventory } \\
\text { (Ci) }\end{array}$ \\
\hline Cs-137 & $34(17)$ & $2.54 \mathrm{E}-10$ & $1.08 \mathrm{E}-03$ & --- & --- & $9.67 \mathrm{E}-02$ \\
\hline $\mathrm{Cm}-244$ & $9(8)$ & $3.16 \mathrm{E}-12$ & $1.35 \mathrm{E}-05$ & --- & --- & $1.20 \mathrm{E}-03$ \\
\hline $\mathrm{Pu}-239$ & $14(8)$ & $2.86 \mathrm{E}-12$ & $1.22 \mathrm{E}-05$ & --- & --- & $1.09 \mathrm{E}-03$ \\
\hline $\mathrm{Pu}-242$ & $2(0)$ & $3.45 \mathrm{E}-09$ & $1.48 \mathrm{E}-02$ & --- & --- & $1.32 \mathrm{E}+00$ \\
\hline
\end{tabular}

${ }^{1}$ Parentheses indicates \#< detection

Indian Grave Br.

\begin{tabular}{|l|c|c|c|c|c|c|}
\hline Radionuclide & $\begin{array}{c}\text { No. } \\
\text { Sediment } \\
\text { Samples }^{\mathbf{1}}\end{array}$ & $\begin{array}{c}\text { Sediment } \\
\text { Mean } \\
\text { Conc. } \\
\text { Ci//kg }\end{array}$ & $\begin{array}{c}\text { Sediment } \\
\text { Inventory } \\
\mathbf{( C i )}\end{array}$ & $\begin{array}{c}\text { No. } \\
\text { Sed/Soil } \\
\text { Samples }\end{array}$ & $\begin{array}{c}\text { Sed/Soil } \\
\text { Mean } \\
\text { Conc. } \\
\text { Ci//kg }\end{array}$ & $\begin{array}{c}\text { Sed/Soil } \\
\text { Inventory } \\
\text { (Ci) }\end{array}$ \\
\hline & & & & & & \\
\hline Cs-137 & $60(23)$ & $5.08 \mathrm{E}-10$ & $1.10 \mathrm{E}-03$ & --- & --- & $9.79 \mathrm{E}-02$ \\
\hline $\mathrm{Co}-60$ & $60(38)$ & $3.41 \mathrm{E}-11$ & $7.37 \mathrm{E}-05$ & --- & --- & $6.57 \mathrm{E}-03$ \\
\hline $\mathrm{Pu}-238$ & $12(2)$ & $7.76 \mathrm{E}-12$ & $1.68 \mathrm{E}-05$ & --- & --- & $1.50 \mathrm{E}-03$ \\
\hline $\mathrm{Pu}-239$ & $12(0)$ & $3.91 \mathrm{E}-11$ & $8.47 \mathrm{E}-05$ & --- & --- & $7.55 \mathrm{E}-03$ \\
\hline
\end{tabular}

${ }^{1}$ Parentheses indicates \#< detection 
Pen Br. Upper

\begin{tabular}{|l|c|c|c|c|c|c|}
\hline Radionuclide & $\begin{array}{c}\text { No. } \\
\text { Sediment } \\
\text { Samples }\end{array}$ & $\begin{array}{c}\text { Sediment } \\
\text { Mean } \\
\text { Conc. } \\
\text { Ci//kg }\end{array}$ & $\begin{array}{c}\text { Sediment } \\
\text { Inventory } \\
\mathbf{( C i )}\end{array}$ & $\begin{array}{c}\text { No. } \\
\text { Sed/Soil } \\
\text { Samples }\end{array}$ & $\begin{array}{c}\text { Sed/Soil } \\
\text { Mean } \\
\text { Conc. } \\
\text { Ci/kg }\end{array}$ & $\begin{array}{c}\text { Sed/Soil } \\
\text { Inventory } \\
\text { (Ci) }\end{array}$ \\
\hline & & & & & & \\
\hline $\mathrm{Cs}-137$ & $9(2)$ & $4.69 \mathrm{E}-10$ & $1.02 \mathrm{E}-03$ & --- & --- & $9.08 \mathrm{E}-02$ \\
\hline Pu-242 & $1(0)$ & $3.47 \mathrm{E}-09$ & $7.53 \mathrm{E}-03$ & --- & --- & $6.72 \mathrm{E}-01$ \\
\hline
\end{tabular}

${ }^{1}$ Parentheses indicates \#<detection 
Table A-0-3 SC Compartments - Samples, Mean Concentrations and Inventories Steel Ck. Lower

\begin{tabular}{|l|c|c|c|c|c|c|}
\hline Radionuclide & $\begin{array}{c}\text { No. } \\
\text { Sediment } \\
\text { Samples }\end{array}$ & $\begin{array}{c}\text { Sediment } \\
\text { Mean } \\
\text { Conc. } \\
\text { Ci/kg }\end{array}$ & $\begin{array}{c}\text { Sediment } \\
\text { Inventory } \\
\text { (Ci) }\end{array}$ & $\begin{array}{c}\text { No. } \\
\text { Sed/Soil } \\
\text { Samples }\end{array}$ & $\begin{array}{c}\text { Sed/Soil } \\
\text { Mean } \\
\text { Conc. } \\
\text { Ci/kg }\end{array}$ & $\begin{array}{c}\text { Sed/Soil } \\
\text { Inventory } \\
\text { (Ci) }\end{array}$ \\
\hline Am-241 & $12(7)$ & $1.50 \mathrm{E}-11$ & $2.04 \mathrm{E}-04$ & --- & --- & -- \\
\hline Cs-137 & $29(0)$ & $2.99 \mathrm{E}-09$ & $4.11 \mathrm{E}-02$ & $48(11)$ & $1.15 \mathrm{E}-08$ & $1.38 \mathrm{E}+01$ \\
\hline $\mathrm{Co}-60$ & $21(15)$ & $9.42 \mathrm{E}-12$ & $1.30 \mathrm{E}-04$ & $40(25)$ & $7.22 \mathrm{E}-11$ & $8.70 \mathrm{E}-02$ \\
\hline $\mathrm{Cm}-244$ & $10(9)$ & $2.52 \mathrm{E}-13$ & $3.47 \mathrm{E}-06$ & --- & --- & --- \\
\hline Np-237 & --- & --- & --- & $1(0)$ & $3.00 \mathrm{E}-10$ & $3.61 \mathrm{E}-01$ \\
\hline Pu-238 & $19(6)$ & $1.35 \mathrm{E}-11$ & $1.86 \mathrm{E}-04$ & $13(3)$ & $8.56 \mathrm{E}-12$ & $1.03 \mathrm{E}-02$ \\
\hline $\mathrm{Pu}-239$ & $21(5)$ & $1.24 \mathrm{E}-11$ & $1.70 \mathrm{E}-04$ & $13(1)$ & $1.08 \mathrm{E}-11$ & $1.30 \mathrm{E}-02$ \\
\hline Sr-90 & $20(17)$ & $1.21 \mathrm{E}-10$ & $1.66 \mathrm{E}-03$ & $19(15)$ & $5.76 \mathrm{E}-11$ & $6.94 \mathrm{E}-02$ \\
\hline
\end{tabular}

${ }^{1}$ Parentheses indicates \#<detection

Steel Creek Middle (L-Lake)

\begin{tabular}{|l|c|c|c|c|c|c|}
\hline Radionuclide & $\begin{array}{c}\text { No. } \\
\text { Sediment } \\
\text { Samples }\end{array}$ & $\begin{array}{c}\text { Sediment } \\
\text { Mean } \\
\text { Conc. } \\
\text { Ci/kg }\end{array}$ & $\begin{array}{c}\text { Sediment } \\
\text { Inventory } \\
\text { (Ci) }\end{array}$ & $\begin{array}{c}\text { No. } \\
\text { Sed/Soil } \\
\text { Samples }\end{array}$ & $\begin{array}{c}\text { Sed/Soil } \\
\text { Mean } \\
\text { Conc. } \\
\text { Ci/kg }\end{array}$ & $\begin{array}{c}\text { Sed/Soil } \\
\text { Inventory } \\
\text { (Ci) }\end{array}$ \\
\hline Cs-137 & & & & & \\
\hline Co-60 & $144(37)$ & $2.69 E-09$ & $3.75 E+00$ & --- & --- & --- \\
\hline Pu-238 & $141(90)$ & $6.10 \mathrm{E}-12$ & $8.50 \mathrm{E}-03$ & --- & --- & --- \\
\hline Pu-239 & $142(117)$ & $2.93 E-11$ & $4.08 E-02$ & --- & --- & --- \\
\hline Sr-90 & $131(89)$ & $2.66 E-11$ & $3.71 E-02$ & --- & --- & -- \\
\hline
\end{tabular}

\footnotetext{
${ }^{2}$ Median value used; ${ }^{1}$ Parentheses indicates \#< detection
} 
Steel Ck. Upper

\begin{tabular}{|l|c|c|c|c|c|c|}
\hline Radionuclide & $\begin{array}{c}\text { No. } \\
\text { Sediment } \\
\text { Samples }\end{array}$ & $\begin{array}{c}\text { Sediment } \\
\text { Mean } \\
\text { Conc. } \\
\text { Ci/kg }\end{array}$ & $\begin{array}{c}\text { Sediment } \\
\text { Inventory } \\
\text { (Ci) }\end{array}$ & $\begin{array}{c}\text { No. } \\
\text { Sed/Soil } \\
\text { Samples }\end{array}$ & $\begin{array}{c}\text { Sed/Soil } \\
\text { Mean } \\
\text { Conc. } \\
\text { Ci/kg }\end{array}$ & $\begin{array}{c}\text { Sed/Soil } \\
\text { Inventory } \\
\text { (Ci) }\end{array}$ \\
\hline Am-241 & & & & & & \\
\hline C-14 & $10(6)$ & $4.20 \mathrm{E}-11$ & $1.01 \mathrm{E}-04$ & --- & --- & --- \\
\hline Cs-137 & $6(3)$ & $1.17 \mathrm{E}-09$ & $2.80 \mathrm{E}-03$ & --- & --- & --- \\
\hline Co-60 & $34(2)$ & $4.16 \mathrm{E}-08$ & $9.97 \mathrm{E}-02$ & $89(3)$ & $7.10 \mathrm{E}-08$ & $3.90 \mathrm{E}+00$ \\
\hline Cm-244 & $30(18)$ & $2.77 \mathrm{E}-11$ & $6.64 \mathrm{E}-05$ & $32(29)$ & $2.20 \mathrm{E}-11$ & $1.21 \mathrm{E}-03$ \\
\hline Ni-63 & $10(7)$ & $3.58 \mathrm{E}-09$ & $8.59 \mathrm{E}-03$ & --- & --- & --- \\
\hline Pu-238 & $6(3)$ & $3.70 \mathrm{E}-09$ & $8.87 \mathrm{E}-03$ & $3(1)$ & $3.24 \mathrm{E}-09$ & $1.78 \mathrm{E}-01$ \\
\hline Pu-239 & --- & --- & --- & $12(9)$ & $2.22 \mathrm{E}-10$ & $1.22 \mathrm{E}-02$ \\
\hline Sr-90 & $22(13)$ & $1.59 \mathrm{E}-11$ & $3.81 \mathrm{E}-05$ & $12(9)$ & $1.25 \mathrm{E}-10$ & $6.86 \mathrm{E}-03$ \\
\hline Tc-99 & $23(19)$ & $6.46 \mathrm{E}-11$ & $1.55 \mathrm{E}-04$ & $14(11)$ & $4.54 \mathrm{E}-10$ & $2.49 \mathrm{E}-02$ \\
\hline Th-230 & $6(5)$ & $2.75 \mathrm{E}-09$ & $6.59 \mathrm{E}-03$ & --- & --- & --- \\
\hline U-234 & $3(0)$ & $8.70 \mathrm{E}-10$ & $2.08 \mathrm{E}-03$ & $19(0)$ & $1.72 \mathrm{E}-09$ & $9.47 \mathrm{E}-02$ \\
\hline U-235 & --- & --- & --- & $28(0)$ & $7.34 \mathrm{E}-10$ & $4.03 \mathrm{E}-02$ \\
\hline U-238 & ---- & --- & --- & $28(15)$ & $5.49 \mathrm{E}-11$ & $3.01 \mathrm{E}-03$ \\
\hline
\end{tabular}

${ }^{1}$ Parentheses indicates \#<detection

Meyers Branch

\begin{tabular}{|l|c|c|c|c|c|c|}
\hline Radionuclide & $\begin{array}{c}\text { No. } \\
\text { Sediment } \\
\text { Samples }^{1}\end{array}$ & $\begin{array}{c}\text { Sediment } \\
\text { Mean } \\
\text { Conc. } \\
\text { Ci/kg }\end{array}$ & $\begin{array}{c}\text { Sediment } \\
\text { Inventory } \\
\text { (Ci) }\end{array}$ & $\begin{array}{c}\text { No. } \\
\text { Sed/Soil } \\
\text { Samples }\end{array}$ & $\begin{array}{c}\text { Sed/Soil } \\
\text { Mean } \\
\text { Conc. } \\
\text { Ci/kg }\end{array}$ & $\begin{array}{c}\text { Sed/Soil } \\
\text { Inventory } \\
\text { (Ci) }\end{array}$ \\
\hline & & & & & & \\
\hline $\mathrm{Cs}-137$ & $23(7)$ & $3.67 \mathrm{E}-11$ & $2.54 \mathrm{E}-04$ & $2(1)$ & $5.09 \mathrm{E}-11$ & $1.54 \mathrm{E}-03$ \\
\hline Pu-239 & $15(14)$ & $1.20 \mathrm{E}-11$ & $8.31 \mathrm{E}-05$ & & & \\
\hline Sr-90 & $17(14)$ & $1.60 \mathrm{E}-10$ & $1.11 \mathrm{E}-03$ & & & \\
\hline
\end{tabular}


SRNL-STI-2013-00592

Revision 0

This Page Intentionally Left Blank 
SRNL-STI-2013-00592

Revision 0

\section{APPENDIX B}

FMB, PB, and SC IOUs Sub-Compartment Dimensions and Computation of Contaminated Soil Volume and Mass 
Table B-0-4. FMB Compartments - Volume and Mass of Contaminated Media

\begin{tabular}{|l|c|c|}
\hline \multicolumn{1}{|c|}{ Lower Compartment } & Sediment & Sed/Soil \\
\hline Representative Length (m) & 9059 & 9059 \\
\hline Representative Width (m) & 7 & 83 \\
\hline Representative Depth (m) & 0.2 & 0.35 \\
\hline Volume of Contaminated Soil $\left(\mathrm{m}^{3}\right)$ & $1.27 \mathrm{E}+04$ & $2.63 \mathrm{E}+05$ \\
\hline Bulk Density of Soil $\left(\mathrm{kg} / \mathrm{m}^{3}\right)^{1}$ & 1650 & 1650 \\
\hline Mass of Contaminated Soil $(\mathrm{kg})$ & $2.09 \mathrm{E}+07$ & $4.34 \mathrm{E}+08$ \\
\hline
\end{tabular}

${ }^{1}$ From Phifer et.al. 2006

\begin{tabular}{|l|c|c|}
\hline \multicolumn{1}{|c|}{ Middle Compartment } & Sediment & Sed/Soil \\
\hline Representative Length (m) & 7700 & 5970 \\
\hline Representative Width (m) & 5 & 67 \\
\hline Representative Depth (m) & 0.2 & 0.35 \\
\hline Volume of Contaminated Soil $\left(\mathrm{m}^{3}\right)$ & $7.70 \mathrm{E}+03$ & $1.40 \mathrm{E}+05$ \\
\hline Bulk Density of Soil $\left(\mathrm{kg} / \mathrm{m}^{3}\right)^{1}$ & 1650 & 1650 \\
\hline Mass of Contaminated Soil $(\mathrm{kg})$ & $1.27 \mathrm{E}+07$ & $2.31 \mathrm{E}+08$ \\
\hline
\end{tabular}

${ }^{1}$ From Phifer et.al. 2006

\begin{tabular}{|l|c|c|}
\hline \multicolumn{1}{|c|}{ Castor Ck. } & Sediment & Sed/Soil \\
\hline Representative Length (m) & 3160 & --- \\
\hline Representative Width (m) & 2 & --- \\
\hline Representative Depth (m) & 0.2 & --- \\
\hline Volume of Contaminated Soil $\left(\mathrm{m}^{3}\right)$ & 1264 & --- \\
\hline Bulk Density of Soil $\left(\mathrm{kg} / \mathrm{m}^{3}\right)^{1}$ & 1650 & --- \\
\hline Mass of Contaminated Soil $(\mathrm{kg})$ & $2.09 \mathrm{E}+06$ & --- \\
\hline
\end{tabular}

${ }^{1}$ From Phifer et.al. 2006

\begin{tabular}{|l|c|c|}
\hline \multicolumn{1}{|c|}{ F-Seepage Area } & Sediment & Sed/Soil \\
\hline Representative Length (m) & --- & 800 \\
\hline Representative Width (m) & --- & 200 \\
\hline Representative Depth (m) & --- & 0.35 \\
\hline Volume of Contaminated Soil $\left(\mathrm{m}^{3}\right)$ & --- & $5.60 \mathrm{E}+04$ \\
\hline Bulk Density of Soil $\left(\mathrm{kg} / \mathrm{m}^{3}\right)^{1}$ & --- & 1650 \\
\hline Mass of Contaminated Soil $(\mathrm{kg})$ & --- & $9.24 \mathrm{E}+07$ \\
\hline
\end{tabular}

${ }^{1}$ From Phifer et.al. 2006 


\begin{tabular}{|l|c|c|}
\hline \multicolumn{1}{|c|}{ F-Area Tributary } & Sediment & Sed/Soil \\
\hline Representative Length $(\mathrm{m})$ & 1585 & 1589 \\
\hline Representative Width $(\mathrm{m})$ & 1 & 2 \\
\hline Representative Depth $(\mathrm{m})$ & 0.2 & 0.35 \\
\hline Volume of Contaminated Soil $\left(\mathrm{m}^{3}\right)$ & $3.17 \mathrm{E}+02$ & $1.11 \mathrm{E}+03$ \\
\hline Bulk Density of Soil $\left(\mathrm{kg} / \mathrm{m}^{3}\right)^{1}$ & 1650 & 1650 \\
\hline Mass of Contaminated Soil $(\mathrm{kg})$ & $5.23 \mathrm{E}+05$ & $1.84 \mathrm{E}+06$ \\
\hline
\end{tabular}

${ }^{1}$ From Phifer et.al. 2006

\begin{tabular}{|l|c|c|}
\hline \multicolumn{1}{|c|}{ H-Seepage Area } & Sediment & Sed/Soil \\
\hline Representative Length (m) & --- & 930 \\
\hline Representative Width (m) & --- & 190 \\
\hline Representative Depth (m) & --- & 0.35 \\
\hline Volume of Contaminated Soil $\left(\mathrm{m}^{3}\right)$ & --- & $6.18 \mathrm{E}+04$ \\
\hline Bulk Density of Soil $\left(\mathrm{kg} / \mathrm{m}^{3}\right)^{1}$ & --- & 1650 \\
\hline Mass of Contaminated Soil $(\mathrm{kg})$ & --- & $1.02 \mathrm{E}+08$ \\
\hline
\end{tabular}

${ }^{1}$ From Phifer et.al. 2006

\begin{tabular}{|l|c|c|}
\hline \multicolumn{1}{|c|}{ H-Area Tributary } & Sediment & Sed/Soil \\
\hline Representative Length (m) & 1235 & --- \\
\hline Representative Width (m) & 0.5 & --- \\
\hline Representative Depth (m) & 0.35 & --- \\
\hline Volume of Contaminated Soil $\left(\mathrm{m}^{3}\right)$ & $2.16 \mathrm{E}+02$ & --- \\
\hline Bulk Density of Soil $\left(\mathrm{kg} / \mathrm{m}^{3}\right)^{1}$ & 1650 & --- \\
\hline Mass of Contaminated Soil $(\mathrm{kg})$ & $3.57 \mathrm{E}+05$ & --- \\
\hline
\end{tabular}

${ }^{1}$ From Phifer et.al. 2006

\begin{tabular}{|l|c|c|}
\hline \multicolumn{1}{|c|}{ Upper Compartment } & Sediment & Sed/Soil \\
\hline Representative Length (m) & 5520 & 5520 \\
\hline Representative Width (m) & 2 & 2 \\
\hline Representative Depth (m) & 0.2 & 0.35 \\
\hline Volume of Contaminated Soil $\left(\mathrm{m}^{3}\right)$ & $2.21 \mathrm{E}+03$ & $3.86 \mathrm{E}+03$ \\
\hline Bulk Density of Soil $\left(\mathrm{kg} / \mathrm{m}^{3}\right)^{1}$ & 1650 & 1650 \\
\hline Mass of Contaminated Soil $(\mathrm{kg})$ & $3.64 \mathrm{E}+06$ & $6.38 \mathrm{E}+06$ \\
\hline
\end{tabular}

${ }^{1}$ From Phifer et.al. 2006 
Table B-0-5. PB Compartments - Volume and Mass of Contaminated Media

\begin{tabular}{|l|c|c|}
\hline \multicolumn{1}{|c|}{ Lower Compartment } & Sediment & Sed/Soil \\
\hline Representative Length $(\mathrm{m})$ & 7324 & --- \\
\hline Representative Width $(\mathrm{m})$ & 5 & --- \\
\hline Representative Depth $(\mathrm{m})$ & 0.2 & --- \\
\hline Volume of Contaminated Soil $\left(\mathrm{m}^{3}\right)$ & $7.32 \mathrm{E}+03$ & --- \\
\hline Bulk Density of Soil $\left(\mathrm{kg} / \mathrm{m}^{3}\right)^{1}$ & 1650 & --- \\
\hline Mass of Contaminated Soil $(\mathrm{kg})$ & $1.21 \mathrm{E}+07$ & --- \\
\hline
\end{tabular}

${ }^{1}$ From Phifer et.al. 2006

\begin{tabular}{|l|c|c|}
\hline \multicolumn{1}{|c|}{ Middle Compartment } & Sediment & Sed/Soil \\
\hline Representative Length $(\mathrm{m})$ & 6480 & --- \\
\hline Representative Width $(\mathrm{m})$ & 2 & --- \\
\hline Representative Depth $(\mathrm{m})$ & 0.2 & --- \\
\hline Volume of Contaminated Soil $\left(\mathrm{m}^{3}\right)$ & $2.59 \mathrm{E}+03$ & --- \\
\hline Bulk Density of Soil $\left(\mathrm{kg} / \mathrm{m}^{3}\right)^{1}$ & 1650 & --- \\
\hline Mass of Contaminated Soil $(\mathrm{kg})$ & $4.28 \mathrm{E}+06$ & --- \\
\hline
\end{tabular}

${ }^{1}$ From Phifer et.al. 2006

\begin{tabular}{|l|c|c|}
\hline \multicolumn{1}{|c|}{ Indian Grave Br. Compartment } & Sediment & Sed/Soil \\
\hline Representative Length $(\mathrm{m})$ & 4370 & --- \\
\hline Representative Width $(\mathrm{m})$ & 1.5 & --- \\
\hline Representative Depth $(\mathrm{m})$ & 0.2 & --- \\
\hline Volume of Contaminated Soil $\left(\mathrm{m}^{3}\right)$ & $1.31 \mathrm{E}+03$ & --- \\
\hline Bulk Density of Soil $\left(\mathrm{kg} / \mathrm{m}^{3}\right)^{1}$ & 1650 & --- \\
\hline Mass of Contaminated Soil $(\mathrm{kg})$ & $2.16 \mathrm{E}+06$ & --- \\
\hline
\end{tabular}

${ }^{1}$ From Phifer et.al. 2006

\begin{tabular}{|l|c|c|}
\hline \multicolumn{1}{|c|}{ Upper Compartment } & Sediment & Sed/Soil \\
\hline Representative Length $(\mathrm{m})$ & 3761 & --- \\
\hline Representative Width (m) & 1 & --- \\
\hline Representative Depth (m) & 0.35 & --- \\
\hline Volume of Contaminated Soil $\left(\mathrm{m}^{3}\right)$ & $1.32 \mathrm{E}+03$ & --- \\
\hline Bulk Density of Soil $\left(\mathrm{kg} / \mathrm{m}^{3}\right)^{1}$ & 1650 & --- \\
\hline Mass of Contaminated Soil $(\mathrm{kg})$ & $2.17 \mathrm{E}+06$ & --- \\
\hline
\end{tabular}

${ }^{1}$ From Phifer et.al. 2006 
Table B-0-6. SC Compartments - Volume and Mass of Contaminated Media

\begin{tabular}{|l|c|c|}
\hline \multicolumn{1}{|c|}{ Lower Compartment } & Sediment & Sed/Soil \\
\hline Representative Length $(\mathrm{m})$ & 5819 & 5819 \\
\hline Representative Width (m) & 5 & 250 \\
\hline Representative Depth (m) & 0.2 & 0.35 \\
\hline Volume of Contaminated Soil $\left(\mathrm{m}^{3}\right)$ & $5.82 \mathrm{E}+03$ & $5.09 \mathrm{E}+05$ \\
\hline Bulk Density of Soil $\left(\mathrm{kg} / \mathrm{m}^{3}\right)^{1}$ & 1650 & 1650 \\
\hline Mass of Contaminated Soil $(\mathrm{kg})$ & $9.60 \mathrm{E}+06$ & $8.40 \mathrm{E}+08$ \\
\hline
\end{tabular}

${ }^{1}$ From Phifer et.al. 2006

\begin{tabular}{|l|c|c|}
\hline \multicolumn{1}{|c|}{ Middle Compartment (L-Lake) } & Sediment & Sed/Soil \\
\hline Representative Area $\left(\mathrm{m}^{2}\right)$ & 4224033 & --- \\
\hline Representative Depth $(\mathrm{m})$ & 0.2 & --- \\
\hline Volume of Contaminated Soil $\left(\mathrm{m}^{3}\right)$ & $8.45 \mathrm{E}+05$ & --- \\
\hline Bulk Density of Soil $\left(\mathrm{kg} / \mathrm{m}^{3}\right)^{1}$ & 1650 & --- \\
\hline Mass of Contaminated Soil $(\mathrm{kg})$ & $1.39 \mathrm{E}+09$ & --- \\
\hline
\end{tabular}

${ }^{1}$ From Phifer et.al. 2006

\begin{tabular}{|l|c|c|}
\hline \multicolumn{1}{|c|}{ Meyers Branch Compartment } & Sediment & Sed/Soil \\
\hline Representative Length $(\mathrm{m})$ & 10500 & 10500 \\
\hline Representative Width (m) & 2 & 5 \\
\hline Representative Depth (m) & 0.2 & 0.35 \\
\hline Volume of Contaminated Soil (m $\left.{ }^{3}\right)$ & $4.20 \mathrm{E}+03$ & $1.84 \mathrm{E}+04$ \\
\hline Bulk Density of Soil $\left(\mathrm{kg} / \mathrm{m}^{3}\right)^{1}$ & 1650 & 1650 \\
\hline Mass of Contaminated Soil $(\mathrm{kg})$ & $6.93 \mathrm{E}+06$ & $3.03 \mathrm{E}+07$ \\
\hline
\end{tabular}

${ }^{1}$ From Phifer et.al. 2006

\begin{tabular}{|l|c|c|}
\hline \multicolumn{1}{|c|}{ Upper Compartment } & Sediment & Sed/Soil \\
\hline Representative Length $(\mathrm{m})$ & 3631 & 3397 \\
\hline Representative Width $(\mathrm{m})$ & 2 & 28 \\
\hline Representative Depth $(\mathrm{m})$ & 0.2 & 0.35 \\
\hline Volume of Contaminated Soil $\left(\mathrm{m}^{3}\right)$ & $1.45 \mathrm{E}+03$ & $3.33 \mathrm{E}+04$ \\
\hline Bulk Density of Soil $\left(\mathrm{kg} / \mathrm{m}^{3}\right)^{1}$ & 1650 & 1650 \\
\hline Mass of Contaminated Soil $(\mathrm{kg})$ & $2.40 \mathrm{E}+06$ & $5.49 \mathrm{E}+07$ \\
\hline
\end{tabular}

${ }^{1}$ From Phifer et.al. 2006 
SRNL-STI-2013-00592

Revision 0

This Page Intentionally Left Blank 
SRNL-STI-2013-00592

Revision 0

\section{APPENDIX C}

\section{Email Correspondence References}


SRNL-STI-2013-00592

Revision 0

Kubilius, W.P., 08/12/2013

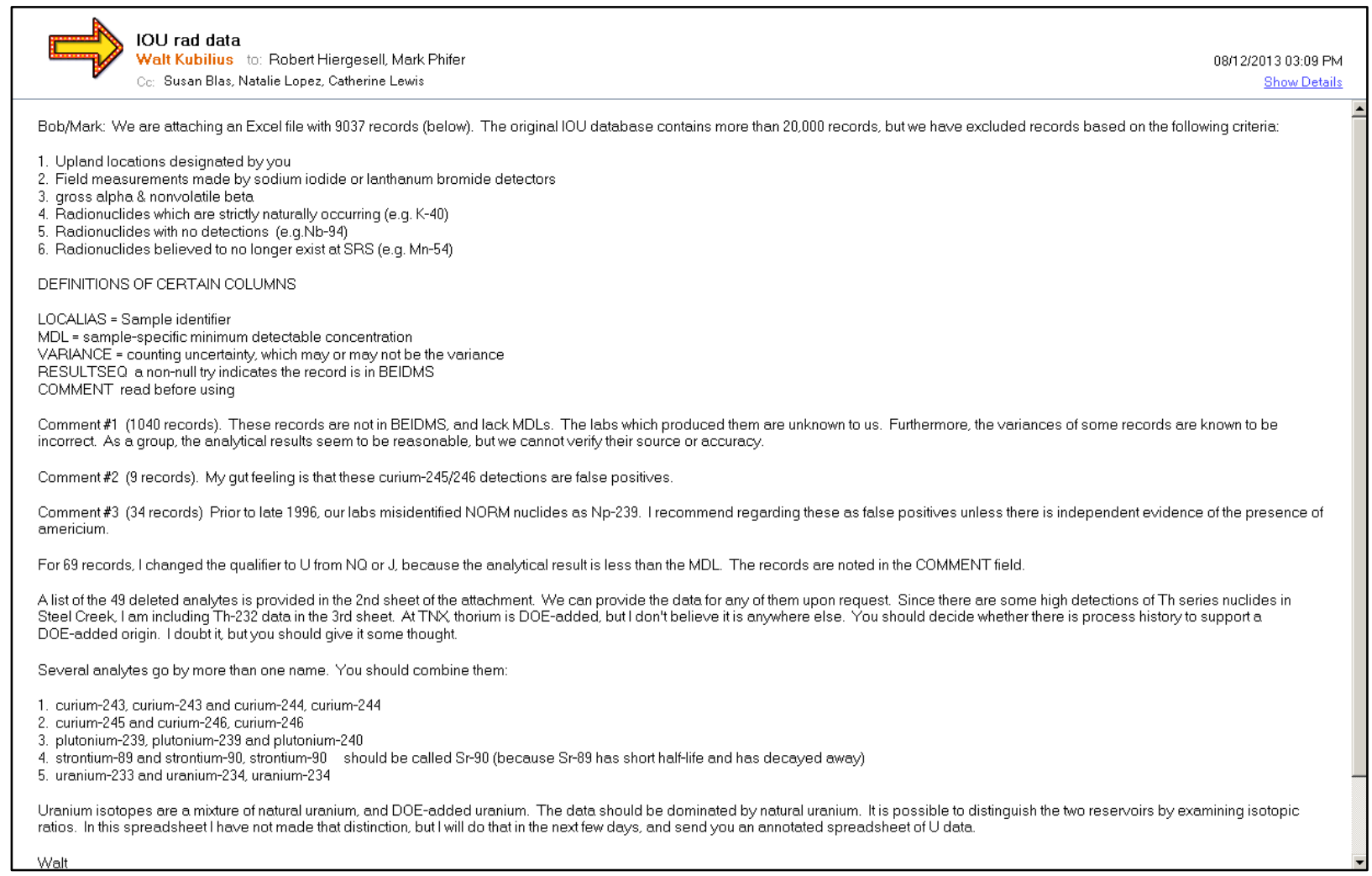


Meeting to discuss considerations for radionuclide inclusion in FMB inventory analysis Attendees: Miles Denham (MD), Tim Jannik (TJ), Mark Phifer (MP), Bob Hiergesell (BH), Walt Kubilius EC\&ACP (WK) - 8/15/2013

The above attendees met to discuss technical issues related to which radionuclides should be tracked in the current investigation to formulate radionuclide inventories for the main channels and floodplains of Fourmile Branch (FMB), Pen Branch (PB) and Steel Creek (SC) IOUs. WK (EC\&ACP) has provided SRNL with the appropriate Sediment and Sed/Soil analytical results for each of these IOUs and made different recommendations. Also, information relevant to the decisions to be made was provided by MP and distributed. The following summarizes the issues discussed and the conclusion that were reached.

Issue of the potential for analytical false positives to occur for certain radionuclide analyses

- Nuclides susceptible for false hits (according to WK) are: Am-241 (from Th-228); C-14 (from H-3); Cm-243/244 (from Ra-224); I-129 (from Cs-137); Ni-63 (from H-3); Pu-238 (from Th-228); Tc-99 (from H-3); and Sn-126 (from NORM)

- $\quad$ Labs have been much more conscientious about guarding against this after approximately 1995. Analyses conducted prior to that ought to be checked to see which method was used, and consideration made as to whether the other nuclides that could cause false hits were present in the sample. (TJ)

- Gamma spectroscopy and liquid scintillation (for C-14 and Tc-99) are the methods that should be screened for in the earlier analyses, as we evaluate the data (MD and TJ)

Issue of whether to consider Uranium isotopes as natural (NORM) or as DOE added (e.g. by mobilization from low $\mathrm{pH}$ disposals in basins or by direct discharge/disposal of $\mathrm{U}$ isotopes).

- $\quad$ TJ and MD thought WK's proposed threshold for U-238 being considered as DOE added was too high. WK proposed U-238 > $10 \mathrm{pCi} / \mathrm{g}$, whenever the U238/U234 concentration is $>1.2$, was a suitable threshold. TJ and MD thought that $1.4 \mathrm{pCi} / \mathrm{g}$ - the value used in the LTR inventory evaluation - is more appropriate. It was agreed that we should use 1.4 $\mathrm{pCi} / \mathrm{g}$ in this study.

- Th-230 also occurs naturally and we agreed to consider it to be naturally occurring if its concentration is $<1.4 \mathrm{pCi} / \mathrm{g}$. (TJ suggestion)

It was agreed upon to evaluate all of the radionuclides listed in MP's Table 1, except for Th-230, U-234, U-235 and U-238 when they are considered to be naturally occurring. Although TJ and MD stated that Co-60 could be deleted, it will be considered because it was included in the LTR inventory estimate.

Ignore the presence of $\mathrm{Cm}-242$ if it shows up in the analyses. Its half-life is $<0.5$ yrs.

It was agreed to exclude the radionuclides listed in MP's Table 2, primarily because of short halflives.

It was agreed to include all of the radionuclides listed in MP's Table 3, if analytical results exist, but the potential for false positives will be considered, as outlined above. 


\section{Distribution:}

R. S. Aylward, 773-42A

S. A. Blas, 730-4B

B. T. Butcher, 773-43A

D. A. Crowley, 773-43A

F. L. Fox, 704-59E

J. C. Griffin, 773-A

M. A. Heitkamp, 999-W

R. A. Hiergesell, 773-43A

G. K. Humphries, 705-3C

G. T. Jannik, 773-42A

T. F. Kmetz, 730-4B

J. J. Kupar, 730-4B

C. M. Lewis, 730-4B

M. G. Looper, 704-36E

J. J. Mayer, 773-42A

M. R. Millings, 773-42A

T. O. Oliver, 773-42A

M. A. Phifer, 773-42A

K. A. Roberts, 773-43A

R. R. Seitz, 773-43A

D. F. Sink, 704-56E

G. A. Taylor, 773-43A

K. L. Tempel, 704-56E

C. Wilson (1 file copy \& 1 electronic copy), 773-43A - Rm. 213 